\title{
3 \\ Linguistics: Inheritance and Innovation in French Guianese Creole
}

\subsection{Theoretical Framework and Corpus Data}

\subsubsection{Introduction}

Until recently (cf. Jennings and Pfänder 2015), FGC counted among the French-based creoles that had not been systematically analysed for possible West African contributions. Neither early work by SaintJacques Fauquenoy (1972), the unpublished but highly detailed description by Peyraud (1983), the short essay by Corne (1971), nor the extensive analysis of the tense and aspect system by Pfänder (2000a, b) insisted on African (and more specifically Gbe) influence on the emergence of FGC. However, the sociohistorical analysis provided in Chap. 2 of this book concludes that Gbe languages were essential to the creation of the new creole in French Guiana. This chapter will test our conclusion from a linguistic viewpoint by building on the work of scholars who reconstruct the interaction of linguistic models in creole genesis. These include Siegel for various creoles, especially from the Pacific, Kriegel and Michaelis for French-based creoles in the Indian Ocean and Migge and Winford for mostly English-based Surinamese creoles. 
The main hypothesis of this chapter is that most FGC grammatical features can be modelled as one of Siegel's four types of transfer from Gbe languages like Ewe, Fon and Gẽ. In cases where the transfer model does not work, we hypothesise that constraints such as the basic word order of French are responsible. We begin our investigation with a discussion of the dichotomy between inheritance and innovation evoked in the book's title (Sect. 3.1.2), before moving on to the usage-based linguistics framework (Sect. 3.1.3), and the four types of transfer (Sect. 3.1.4). These conceptual approaches will then be applied to the analysis of features of the FGC noun phrase (Sect. 3.2), verb phrase (Sect. 3.3) and sentence structure (Sect. 3.4).

\subsubsection{Inheritance and Innovation}

Traditionally, linguistic continuity, often worded as 'inheritance', links the emergence of creole languages to only one linguistic 'parent', but this metaphor is tenuous given that languages are transmitted socially rather than genetically. If any, FGC has more than one 'parent' since Portuguese preceded French in the colony. In addition, the Arawak pidgin was a long-standing lingua franca, and Gbe languages such as Ewe, Fon and Gẽ were used persistently by slaves during at least the first fifty years of colonisation. The multilingualism of slaves and the presence of other African languages also need consideration. Even though most of FGC's lexicon derives from French, other languages should not be ignored. As will be shown in this chapter, the creole's grammar shows influences from both Romance languages (forms and word order) and Gbe languages (functions, strategies and categories). In such complex linguistic cases, it is difficult to apply conventional linear genealogy based on speciation, in which a language slowly diverges from its parent. Instead, inheritance from multiple sources driven and shaped by social factors seems a more likely approach to follow (Enfield 2005).

Linguistic innovation has been conceptualised in many ways. Matthews defines it as "[a]ny change by which a language diverges from others historically related to it" (2014: 196) and offers as an example the innovative word order of the modern English construction, clearly 
I have lost, which contrasts with the verb-second order found in Old English. Some scholars distinguish between "innovation" (an individual act by a speaker) and "change" (the incorporation into a language of innovations) (Milroy and Milroy 1985: 381). Others consider innovation to be "any element of usage (or grammar) which differs from previous usage (or grammars)" (Andersen 1989: 13). This is the view we subscribe to here because it is much in line with the usage-based framework we advocate in this chapter.

Such a usage-based approach aims to reconstruct the manner by which a specific speech community actually communicated-and changed its language use over time (cf. Cheshire 2006: 426). In this sense, innovation goes beyond individual choice as it has to survive a social process of selection within a community before it becomes part of the community's language (Whitney 1979: 149-150; Patrick 2006: 578). This approach is very much in line with Labov's early claim that "no change takes place in a social vacuum. Even the most systematic chain shift occurs with a specificity of time and place that demands an explanation" (1963: 274). Hence, the historical chapter has explored the "agents of change" that have triggered linguistic developments (Eckert 2008; Kerswill 1996, 2006).

Our study contributes to these considerations of inheritance and innovation in several empirically and theoretically relevant ways. First, our FGC corpus data shed light on the variety spoken in the rainforest (cf. Pfänder 2000a), as opposed to the coastal variety that has been the exclusive focus of publications so far (e.g. Schlupp 1997) despite being influenced by other creoles (notably from Martinique and Haiti). Similarly, we study contact varieties of the principal lexifier by consulting a spoken corpus of French (www.ciel-f.org/vitrine) rather than standard French grammars.

We have chosen Ewe, Fon and Gẽ as widely spoken Gbe languages, with a particular emphasis on Ewe, due to the presence of slaves on the Rémire plantation in 1690 who came from areas where that language is now spoken. Although there may have been significant demographic changes since the seventeenth century, the three languages were likely familiar to most of French Guiana's first slaves, and, for want of historical data and a spoken corpus of the language, we will test their possible 
impact through the analysis of modern Gbe grammars. In our study, the specific features of the language contact situation in French Guianawhich are substantially different than in other colonial contexts-play an important role. However, linguistic innovations cannot always be directly attributed to such language contact ("contact-induced innovations"); they also arise "internally" within a community (Cox 2013: 57-58). In a nutshell then, inheritance encompasses transmissions from various ancestor languages, and innovation subsumes both re-combining features and the making of a new system out of usage experiences.

\subsubsection{Experience Counts: The Usage-Based Linguistics Framework}

In terms of theory, we proceed from the central claim of usage-based linguistics, namely that linguistic structures emanate from usage events (Langacker 1987; Bybee 2006). The usage-based model assumes that "grammar is held responsible for a speaker's knowledge, of the full range of linguistic conventions, regardless of whether these conventions can be subsumed under more general statements" (Langacker 1987: 494). In a very similar vein, Joan Bybee (2006) claims grammar "to be the cognitive organisation of one's experience with language":

A usage-based view takes grammar to be the cognitive organisation of one's experience with language. Aspects of that experience, for instance, the frequency of use of certain constructions or particular instances of constructions, have an impact on representation that is evidenced in speaker knowledge of conventionalized phrases and in language variation and change. (Bybee 2006: 711)

In other words, our experience with both spoken and written language makes us develop probabilistic expectations. What we hear of any language or variety during our everyday interactions is what "counts" as our linguistic experience. Interestingly, this approach has not been used for language contact situations in which it would apply perfectly.

Beyond being a mere theorem, this experience-oriented approach to language has major implications for modelling the emergence of new 
linguistic structures or, as it were, of entirely new language systems, as in the case of creolisation.

Being in a contact situation thus means that when we try to perceive structures via similarity and difference, via pattern recognition and categorisation, we happen to be "building" language, and in some cases, to be building "a new language" — not because we lack consistent input or established competence, but because of our general cognitive abilities:

The proposal presented here is that the general cognitive capabilities of the human brain, which allow it to categorize and sort for identity, similarity, and difference, go to work on the language events a person encounters, categorizing and entering in memory these experiences. The result is a cognitive representation that can be called a grammar. This grammar, while it may be abstract, since all cognitive categories are, is strongly tied to the experience that a speaker has had with language. (Bybee 2006: 711)

Experience counts toward a better understanding of grammar. This chapter begins with this somewhat radical claim of usage-based linguistics, namely the idea that the perception of language use in contact situations impacts both on individuals' processing and, in the end, on the emergence of entirely new linguistic structures in contact-induced language change and creolisation (for more details, see Siegel 2008b, 2010, 2012; Pfänder and Palacios 2014; Jennings and Pfänder 2015; Winford 2003).

Many fine-grained empirical analyses have demonstrated that theories of language acquisition and change cannot ignore usage-based explanations such as entrenchment, analogy, salience or frequency effects (Behrens 2009). It is time to examine these topics in creole emergence and contact-induced language change and to investigate whether similar processes are at work in those areas. The remainder of this introduction covers usage-based research and applies it to some of the core grammatical features of FGC.

To paraphrase Pfänder and Behrens (2016), we might say that language contact affects perception, and perception affects learning because reduced elements are less salient and therefore harder to learn. This, 
in turn, affects the language system. In contact language-learner varieties, for example, non-salient elements are often omitted. While first-language learners have enough exposure to ultimately turn their attention to fine morphological details, second-language learners in contact situations often ignore them because they are difficult to perceive and functionally redundant since the respective grammatical information is often also coded within other elements.

In spoken language, we-as hearers-have the task of segmenting the stream of sound we listen to. If certain items happen to occur together very frequently, our memory does not trace the items individually, but rather their co-occurrence. This is known in usage-based linguistics as entrenchment (cf. among others Blumenthal-Dramé 2012; Hilpert and Diessel 2016; Seton and Schmid 2016). Entrenchment facilitates the retrieval of more complex items because they are processed as a fused unit. If such units are fossilised, we speak of chunking, which is one of the basic prerequisites for many processes of lexicalisation and grammaticalisation. In grammaticalisation, more often than not, previously independent items are fused and the new gestalt is no longer a lexeme, but instead acquires a grammatical function. Hopper and Traugott (2003) have emphasised how useful the study of the usage frequency of entrenchment is for a better understanding of the building and dismantling of forms and constructions, or, in other words, the initial phase of processes of grammaticalisation. The forms gonna $<$ going to and gotta < have got to and their emergence in overseas varieties of English are a good example here (Lorenz 2012, 2013).

Chunking may also lead to the phonetic reduction effect, which is the blurring and even loss of morphological boundaries between formerly separated items (cf. Bybee and Thompson 1997). In English, for example, as Krug (2003) has shown, palatalisation at the morphological boundaries between verbs and the pronoun you occurs more often in the frequently used don't you than in the rarer good you (came). Similarly, the phrase let's can thus become opaque in colloquial English and take extra pronouns, as in let's you and him fight (cf. Hopper and Traugott 2003: 12-16). In French-based creoles, the usage-based approach explains forms of entrenchment like the agglutination of the definite article: 
(1)

larie street

'street' (Parépou 1885: 18)

However, there are many more types of entrenchment in FGC.

(2) Yé pa trouvé pyès granmoun
3PL NEG find NEG adult

'They didn't find any adult.' (Holder 1988: 11)

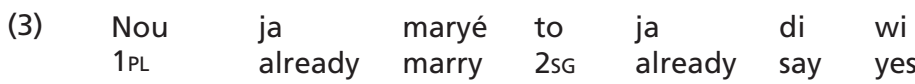

aprézan to pri

now 2sg take

'We are already married. You already said yes; now, you are taken.' (CIEL_FR_GF_RADIO)

(4) I gen sa osi $\mathrm{ki}$ pouvé ekspliké nou poukisa 3SG have DEM also REL can explain 1 $1 \mathrm{PL}$ why 'There are also those who can explain the reason to us...' (CIEL_FR_GF_RADIO)

The cases of reanalysis that lead to entrenchment usually concern two fused items with occasional cases of three, such as dlo, latowè, poukisa and tibonnomme. We find different types of entrenchment, as illustrated in the following section:

a. Definite article agglutination: lari (la rue), larout (la route), lapwent (la pointe), lavi (la vie), lakaz (la case), lèr (l'heure), zarb (les arbres), lapli (la pluie), lanmò (la mort).

b. Possessive pronouns: mopa (ma part).

c. Partitive: diri (du riz), dlo (de l'eau), difé (du feu), dmaten (du matin), dilèt (du lait), dité (du thé), diven (du vin), dipen (du pain).

d. Negation/loss of function: nenpòt (n’importe), pókó (pas encore).

e. Interrogative pronouns: kitan (qui temps), poukisa (pour qui ça), aksa (('’est) qui ça). 
f. Syntactic entrenchments: épi (et puis), konsa (comme ça), annan (en dedans), ka (qu’a), ké (qu'aller), latowè (là tu vois), ya (eux là), jodla (jour là).

g. Lexical entrenchments: bondyé (bon dieu), bonmaten (bon matin), paregsamp (par example), tifiy (petite fille), tigarson (petit garcon), tibonnomme (petit bonhomme), timoun (petit monde), tipoul (petite poule).

Experience does count and, crucially, goes beyond the mere perception of usage frequencies. The strength and nature of experience is also influenced by processing factors such as the context in which a unit occurs, its perceptual salience and memory-related factors such as recency. Constructions in contact depend on the timeframe in which they occur. A recent speech event has a greater influence on how a current speech event is processed than does an older one. This effect can be derived from the structure of memory and has been documented repeatedly in language processing (Szmrecsanyi 2006; Poplack and Tagliamonte 1996; Ellis 2012). Recency has been shown to be important for language change (Rosemeyer 2014) but is not considered here because of the lack of historical corpora of FGC. Salience, though, will be shown to play an important role in the reconstruction of creole genesis (cf. Sect. 3.5.).

In addition to recency and salience, other factors (including social context) play a crucial role in how speakers (and hearers) perceive linguistic structures (cf. Pfänder and Behrens 2016; Ambridge et al. 2015). Ambridge et al. (2015) demonstrate through a variety of studies how situational, social and individual aspects of interaction influence the intake of the input. Other factors such as the social setting or the attitude of the participants may be highly relevant, as well; these factors are rather difficult to put in direct causality with language change (but see Ennis 2008; Ennis and Pfänder 2013).

Similarity effects have been postulated to operate in cross-linguistic language processing (Cutler et al. 2003) and in language contact settings (Jarvis and Pavlenko 2008; Palacios and Pfänder 2014) based on the notion that speakers always build on previous linguistic knowledge and attempt to frame new material as identical or analogous to what they already know. As Cacciari has stated, "Similarity is thus a process 
of alignment and mapping of interconnected structures and systems of knowledge" (1995: 10).

Within a usage-based approach, the perception of similarity by the speakers of language $A$ and language $B$, which is essential for triggering a convergence process (Baptista et al. 2014), is conceptualised in terms of "perceived similarity", a notion developed in the realm of L2 acquisition by Jarvis and Pavlenko (2008). A speaker perceives categories and/ or patterns in the L2 in a different manner than an L1 speaker of that language or a linguist would:

A perceived similarity is a conscious or unconscious judgment that a form, structure, meaning, function, or pattern that an L2 user has encountered in the input of the recipient language is similar to a corresponding feature of the source language. (Jarvis and Pavlenko 2008: 179)

Jarvis and Pavlenko's definition of assumed similarity is in line with the assumption underlying non-contact-induced language change common in the recent cognitive literature, namely that speakers must be considered "pattern seekers". This idea also applies to the concept developed in Kriegel et al. (2009, 2017). Its application to contact-induced language change is discussed in the following section.

\subsubsection{How Experience Counts in Contact: Four Types of Linguistic Transfer}

Based on Siegel $(2012,2015)$ and, in a similar vein, on Jennings and Pfänder (2015), we propose four types of linguistic transfer in creolisation:

1. Functional transfer Type 1 or 'functionalisation': A lexeme acquires a grammatical function.

2. Functional transfer Type $\mathbf{2}$ or 'refunctionalisation': The functional range of a grammatical item or construction is extended and/or reduced.

3. Morphosyntactic strategy transfer: Linguistic transfer promotes a morphosyntactic strategy that is originally only marginally present andlor a word order that is highly productive in the contact language. 
4. Category transfer: Transfer leads to the stronger routinisation of a semantically defined category that is originally only marginally grammaticalised.

\subsubsection{Functionalisation}

The source of this Type 1 linguistic transfer process is a language B feature that has not yet or only weakly been grammatical(ised) but is perceived as being similar to a grammatical(ised) feature of language A (cf. Pfänder 2000; Ludwig and Pfänder 2003; Bruyn 1996, 2011 on the debate about grammaticalisation in creoles). The language B feature in question is the less-frequently used of the two possible variants of the language. Through transfer, the less-frequent variant is promoted. The other variant, lacking an equivalent in the contact language (language A), may undergo a decrease in frequency or even become lost:

Functionalisation is defined as applying the semantic/functional properties of a grammatical morpheme of a substrate language to a lexical morpheme of the lexifier or to a free grammatical morpheme that has completely different functions. When it occurs, the morphosyntactic strategy of the substrate language for expressing those functions is also adopted. This results in a change in morphological type and therefore the creation of a new grammatical morpheme that is not found in the lexifier. (Siegel 2015: 169)

Transfer through functionalisation can be found, for example, in the emergence of the Haitian Creole progressive marker ap 'after', which is said to be based on a structure that exists in north-western varieties of French 'to be doing'. The more frequent variant 'to be in the train of doing', which has no equivalent in West African languages, is not picked up. Hence, 'to be after doing', the originally infrequent and geographically limited variant of language B develops into the regular progressive marker in some French-based creoles.

\footnotetext{
${ }^{1}$ Bruyn (1996: 42) defines apparent grammaticalisation as "the transfer of the result of a process of grammaticalization that has taken place in another language" [our emphasis].
} 


\subsubsection{Refunctionalisation}

The term refunctionalisation (Transfer Type 2) was first introduced in Jennings and Pfänder (2015) and has been taken up by Siegel (2015), who gives the following definition:

Refunctionalisation is defined here as applying the semantic/functional properties of a grammatical morpheme in a substrate language to an existing grammatical morpheme that has been acquired from the lexifier. In contrast to functionalisation, it follows the morphosyntactic strategy of the lexifier, not the substrate language(s), and does not result in a new grammatical morpheme, but rather an extension or contraction of the semantic/functional properties of an already existing morpheme from the lexifier. (Siegel 2015: 169)

The source of a Type 2 transfer process is thus a language B feature that is already grammatical(ised) and perceived as being similar to a grammatical(ised) feature of a language A. In contrast to Type 1, however, there is no variability between features. In Type 2 convergence tendency, a grammatical(ised) feature of language $\mathrm{B}$ is refunctionalised on the grounds of its similarity to a grammatical(ised) feature in the speaker's language A. This type of convergence can be found in the refunctionalisation of the Spanish past perfect tense marking as an evidential or mirative marker in Andean Spanish. L1 speakers of Quechua have been argued to perceive a metonymic similarity between the temporal distancing function of the Spanish past perfect and the epistemic distancing function of Quechua evidential markers (Pfänder 2009). This metonymic similarity has thus been argued to provide the basis for the refunctionalisation.

\subsubsection{Morphosyntactic Strategy Transfer}

We define instances of morphosyntactic strategy as belonging to Type 3 . Morphosyntactic - in creoles mostly syntactic - strategy refers to a process by which structures from a source language $\mathrm{A}$ are introduced to a typologically different language $\mathrm{B}$. The strategy of using reduplication to 
mark an increase in intensity, for example, which is strongly grammaticalised in West African languages, is introduced to French, a language that is (a) typologically different and (b) does not use reduplication to mark an increase in intensity. Siegel elaborates on the type of transfer:

Morphosyntactic strategies include various morphological processes - for example, types of affixation or reduplication - that are used to express grammatical meaning. The most important substrate languages in the development of Bislama were the Eastern Oceanic language of central Vanuatu. Many of these languages use partial reduplication for various grammatical functions: with verbs, to show random or repeated action and with adjectives to indicate plural and distributive. (Siegel 2015: 162)

\subsubsection{Category Transfer}

We identify the transfer of semantically defined categories as belonging to Type 4. During the transfer, a new category is introduced and matched onto the form of an existing category, which in turn disappears. Siegel writes:

The linguistic transfer of grammatical categories follows on from conceptual transfer of the semantic categories on which they are based. One substrate language, Nunggubuyu, has a separate grammatical marker maker for six semantic roles; the others have collapsed some of the semantic roles together into one grammatical category, such as goal and location, which both have the same case marker. (Siegel 2015: 165f)

In contrast to Type 3 (morphosyntactic strategy), transfer processes that follow Type 4 (category transfer) introduce a category that did not receive a grammaticalised expression in the target language prior to the transfer process. In French, for example, there is no grammatically expressed category like the spatial copula "to be at a certain place", whereas in Portuguese, this category is expressed by ficar "to be located at/in". In FGC, the locative copula fika can be considered the result of semantic category transfer. 


\subsubsection{Data and Sources for French Guianese Creole}

The first textual evidence of FGC dates back to 1744, and other pieces of evidence come from 1797 to 1824 . The principal nineteenth-century sources are an 1848 abolition proclamation (Sournia 1976: 3-8); a grammar accompanied by fables, songs and poems (Saint-Quentin 1872); and a fictional text written in a conversational and familiar style, Atipa (Parépou 1885). The first novel in FGC, it was written by Pierre Félix Athénodor Météran under the pseudonym of Alfred Parépou. The novel was first published in Paris in 1885 and tells the story of Atipa and his compatriots, revealing impressions of the colonial French Guianese language, culture and society. Principal twentieth-century sources are the studies and corpora by Tchang (1988), Contout (1973), Honorien (2010), Horth (1948), Jennings (1999), Peyraud (1983), Schlupp (1997), Pfänder (1996, 2000a, b, 2013) and Saint-Jacques Fauquenoy $(1972,1974)$. A dialect of FGC is described by Corne (1971). Despite obvious differences to French (and other lexically French-based creoles), descriptions of FGC are often influenced by French (and other creole) categories and translations.

In addition to the sources cited, we use a wide range of linguistic data, most importantly a sizeable quantity of recordings made in 1995 (from West to East, from North to South) in Mana, Organabo, Iracoubo, Corossony, Sinnamary, Kourou, Savanne Maya, Cayenne, Rémire, Roura, Ouanary, Saint-Georges, Maripasoula and Saül. We include a choice of excerpts of this corpus in the Appendix of this study; we deliberately choose transliterations that are appealing both linguistically and anthropologically.

In the pluriglossic language community of French Guiana, situations in which only one language is used are very rare. Among other factors, the speakers' parents are an important issue here: it is difficult to find a speaker who does not have at least one parent from Martinique due to strong immigration since the eruption of Mount Pelée in 1902. Linguistic integration is problem-free due to the similarity of the two creole languages and sociopolitical contexts, both territories being French overseas departments. 
With the help of the respective host family, Pfänder was able to make recordings in which individual family members or their friends talked with neighbours or relatives. Subject areas were agreed upon with one of the informants in the conversation to promote the thematic comparability of the material. The subject areas also included a well-considered order and associative "bridges" to remove social distance within the course of a longer conversation. The topics of conversation included education, work and magic.

The pluriglossic situation in the country is a subject worthy of linguistic research in and of itself. Some pointers regarding the geolinguistic situation, which is usually subject to much speculation, can be given. The creole spoken in Saül and Maripasoula, which are located in the rainforest, is particularly susceptible to the influence of the creole of St. Lucia because these two places developed as gold-digger towns, with the majority of the gold-diggers coming from St. Lucia. French Guiana continues to display a high rate of migration to this day, mainly for occupational reasons (cf. Léglise and Migge 2007). As a result, the rural-urban distinction can only be applied to some degree. The same circumstance may also be the reason for the fact that, at least at the morphosyntactical level and to a lesser degree at the lexical and phonetic levels, only minor differences can be found between the two places, which are located a great distance from one another and were often quite isolated. What does stand out, however, is the very specific prosodic structure of the creole spoken in Ouanary and St. Georges, places that are under the influence of both Portuguese and a language that belongs to the Arawak language family. FGC there has often been learned as an L2, which is rather rare for a creole language. In general, it can be said that the primeval forest communities were rather productive regarding the recordings of a creole that has had little contact with the French language.

Close to the coast, language contact situations are more or less restricted to European languages and Martinique Creole. It is interesting, though, that when looking for a creole that has only little contact with other languages, the so-called five-house settlements that can be found on the map are usually unproductive despite their isolated location since the younger population works in Cayenne or Kourou and commutes regularly. Many of the settlements have been deserted. People 
who speak FGC on a daily basis still can be found in little towns near the coast (Iracoubo, Sinnamary) and in very isolated settlements.

In addition to the 1995 recordings, we have material collected between 1995 and 2016 comprising audio recordings, school books, radio transmission, YouTube clips, Facebook posts and Twitter messages. This data set is the first in the study of FGC to consider both recordings from the rainforest hinterland and social media contributions. The Internet data allow us to draw some real-time comparisons between the 1995 fieldwork and today. The following excerpts provide a quick impression of the contemporary usage of FGC. Some of the following excerpts were taken from a program on 'Radio RFO Guyane' and transcribed for the corpus CIEL_F for the investigation of French. Here, we focus on the paragraphs with code-switching between French and Creole:

$\begin{array}{lllllll}\text { (5) [French] } & \text { Son } & \text { mari, } & & \text { il } & \text { dit: } & \\ & \text { POSS } & \text { husband } & & \text { 3sG } & \text { say.3sG } & \\ \text { [Creole] } & \text { 'Nou } & \text { ja } & \text { maryé, } & \text { ba } & \text { mo } & \text { ronflé. } \\ & \text { 3PL } & \text { already } & \text { married } & \text { give } & \text { me } & \text { snore } \\ & \text { Menm } & \text { si } & \text { mo } & \text { pyé } & \text { ka } & \text { santi } \\ & \text { even } & \text { if } & \text { POSs.1sG } & \text { feet } & \text { PROG } & \text { stink } \\ & \text { c'est } & \text { pas } & \text { grave.' } & & & \\ \text { [French }] & \text { be.3sG } & \text { NEG } & \text { bad } & & & \end{array}$

'[in French] her husband says: [in Creole] 'We are married, (so) let me snore. Even if my feet stink, [in French] it doesn't matter.'

Pioneering work in various other creole languages and contact varieties provides a model to be followed in French Guiana. Increasing contact between speakers of other contact languages on the Internet creates playful experiences in which these languages become intercomprehensible:

(6) sé moun-yan bonjou^^^

je suis camerounais et franchement j'aime graaaave le créole, surtout l'accent; Et je voulais vraiment élargir mon vocabulaire créol, pck je connais kelke petit mot.

'Hello guys! (in FGC; he then goes on in French) I am from Cameroon and honestly, I reeeeeally like the Creole language, especially the accent; and I would actually like to enhance my vocabulary in Creole because I already know a few words.' 
The Internet thus offers a global platform to make visible and audible what once was merely local (cf. Mair and Pfänder 2013).

It is not only the creole data that are unique for both fieldwork data and social media data, but also the use of newly available resources of French that we choose as an empirical ground for our analysis in the following sections. In studying French as the main lexifier, we rely upon the first large corpus of spoken French worldwide, CIEL-F (www.cielf.org/vitrine; Pfänder et al. 2012). This corpus covers twenty regions of the French-speaking world, offering spontaneous data in audio and video recordings (Mondada and Pfänder 2016).

To test the influence of West African Gbe languages on FGC is to enter new territory. We use as our principal focus the Gbe languages Ewe, Gê and Fon, which are widely spoken in and around the coastal area where many of French Guiana's first slaves originated. Features listed in the Atlas of Pidgin and Creole Language Structures (Michaelis et al. 2013; Pfänder 2013) serve as our basis for comparison, and we ground our exploration of FGC's grammar in Siegel's (2007, 2012, 2015) typology of transfer. As opposed to his method of illustrating different categories with examples from various creole languages, we test all of the proposed types of transfer with the grammar of FGC. This task provides the structure of the following sections, which cover the noun phrase (Sect. 3.2), the verb phrase (Sect. 3.3) and sentence structure (Sect. 3.4).

\subsection{Noun Phrase}

\subsubsection{Indefinite Article}

FGC has both a definite and an indefinite article. The indefinite article oun (allegro form ' $n$, emphatic form roun) precedes the noun or the noun phrase, just as in French:

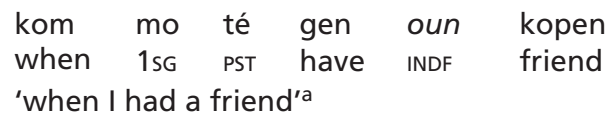

aThis and all other unattributed quotes of FGC are drawn from the FGC corpus (see Appendix). 
(8) To ka wè a pa oun lavie 2sG PROG see DEM NEG INDF life 'You see, this is not a life.' (CIEL_FR_GF_RADIO)

(9) Bèt-ai 'n pé rèd. thing-SG.DEF 3sG INDF little bit difficult 'This thing is a little bit difficult.' (CIEL_FR_GF_RADIO)

(10) Mo ka fè 'n mayouri.

1sG PROG make INDF mayouri

'I am going to organise a mayouri (i.e., a cooperative work session).'

Unlike French, the indefinite article makes no gender distinction (oun wonm/oun fanm):

$\begin{array}{llllllll}\text { Paské } & \text { i } & \text { gen } & \text { oun } & \text { wonm } & & & \\ \text { because } & \text { 2sG } & \text { have } & \text { INDF } & \text { man } & & & \\ \text { té } & \text { ka } & \text { fè } & \text { oun } & \text { chanté } & \text { anlé } & \text { oun } & \text { wonm } \\ \text { PST } & \text { PROG } & \text { make } & \text { INDF } & \text { song } & \text { about } & \text { INDF } & \text { man }\end{array}$

'Because there was a man who sang about another man.'

(12) Yé ka tann oun fanm, oun madanm. 3PL PROG hear INDF woman INDF lady

'They heard a woman, a lady.'

(13) To $\mathrm{ka}$ di to pran oun sèl fanm. 2sG PROG say 2sG take INDF single woman 'You say that you have only one woman.' (CIEL_FR_GF_RADIO)

An interesting difference with French is that the indefinite article is not used for generic meanings in the FGC corpus:

$$
\begin{aligned}
& \text { Akisa? A kaz! } \\
& \text { what-this this house! } \\
& \text { 'What is this? This is a house.' }
\end{aligned}
$$


Ewe shows a similar omission of the indefinite article in this context:

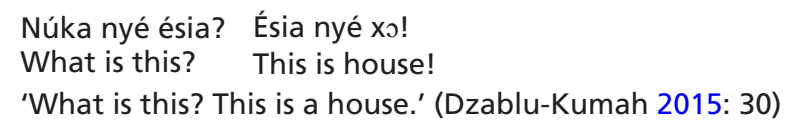

As in Ewe, the indefinite article may also be omitted in generic contexts:

$$
\begin{array}{llll}
\text { Wonm ka fè } & \text { so } & \text { zafè. } \\
\text { man PROG } & \text { make } & \text { POSs } & \text { thing } \\
\text { 'A man does what he wants.' (CIEL_FR_GF_RADIO) }
\end{array}
$$

In the modern media, however, we observe both the omission (example above) and the use (example below) of the generic indefinite article, the latter possibly following the French model:

$$
\begin{aligned}
& \text { Oun fanm ka fè so zafè } \\
& \text { INDF.SG woman PROG make POSs.3sG thing } \\
& \text { 'A woman does what she wants.' (CIEL_FR_GF_RADIO) }
\end{aligned}
$$

Unlike other French creoles in the Caribbean but very much like Ewe, FGC has a plural form of the indefinite article. In Ewe, the plural form is as follows:

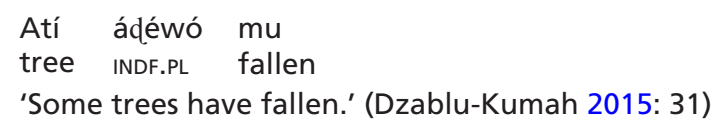

In FGC, speakers use the indefinite article dé:

$$
\begin{array}{llll}
\text { I té gen dé } & \text { ròt kannon. } \\
\text { 3sG PST have INDF.PL } & \text { other boat } \\
\text { 'There were some other boats.' } &
\end{array}
$$

However, the plural form tends to be omitted, as in the following example:

$$
\begin{aligned}
& \text { I gen moun ki fè l' } \\
& \text { 3sg have people REL do it } \\
& \text { 'There are people who do it, you know.' }
\end{aligned}
$$


FGC may have inherited the preposed indefinite article from French and Portuguese, in both form and functions. However, there is possible innovation because the form may be influenced by the Portuguese um, and the functions do not cover the same range as in French. The article is not used in FGC for presentative or generic contexts, which correspond to its use in Ewe. Ewe could thus have been a model for a refunctionalisation of the indefinite article in FGC. However, Ewe has no influence on the position. As in French and Portuguese but unlike Ewe, the indefinite article is preposed to the noun. If we take for granted the constraint established by Andersen (1983), there was no slot to which the postposed Ewe article could be transferred. In the following section, however, we see that Ewe speakers may have perceived a possible slot for the definite article.

\subsubsection{Definite Article}

The definite article occurs after the noun. There is allomorphic variation in this particle depending on the phonemes of the final syllable; the forms are $-a$ (boug-a 'the guy') and -an when following $/ \mathrm{n} / \mathrm{or} / \mathrm{m} /($ fanm-an 'the woman'):

(21) Boug-a ka las

guy-DEF PROG tired

'This guy is tired.' (CIEL_FR_GF_RADIO)

(22) Fanm-an té ka brè woman-DEF PST PROG drink

'The woman used to drink.'

(23) Kaz-a toujou prop house-DEF always clean

'The house is always clean.' (CIEL_FR_GF_RADIO)

(24) Sa genre de jeu-a...

DEM kind of game-DEF

'This kind of game.' (CIEL_FR_GF_RADIO) 
$\begin{array}{lllllll}\text { (25) Nou tandé } & \mathrm{I}^{\prime} & \text { hein nou tandé } & \text { mo-a. } \\ \text { 1 PL } & \text { hear } & \text { 3sG } & \text { right } & \text { 1PL heard word-DEF }\end{array}$ 'We heard it, you know...we heard the word.' (CIEL_FR_GF_RADIO)

The syntactic make-up of the definite article exhibits features of both Transfer Type 2 (refunctionalisation) and Transfer Type 3 (transfer of (morpho)syntactic strategies). In terms of syntactic strategy, the FGC structure closely follows the Ewe pattern of a postposed article in which the article is placed behind the noun phrase, as in (lit.) house the (first example) and house big the (cf. example 27). In FGC, we find:

(26) kaz-a

house-DEF

'the house'

(27) kaz gran $a(n)$

house big DEF

'the big house'

This is quite similar to what we find in Fon (cf. Akoha 2010: 87) or in Ewe:

(28) xolá

house DEF

'the house' (Dzablu-Kumah 2015: 4)

(29) tó lá

mountain DEF

'the mountain' (Eklou 1987: 36)

(30) xo lolo lá

house big DEF

'the big house' (Dzablu-Kumah 2015) 


$$
\begin{aligned}
& \text { tó kóḱ́ lá } \\
& \text { mountain high DEF } \\
& \text { 'the high mountain' (Eklou 1987: 41) }
\end{aligned}
$$

Due to the omission of an explicit copula, placing the definite article in the final example ('the big house') directly after the noun would change the meaning completely by shifting it from an NP to a simple sentence, both in Ewe (first example) and in FGC (second example):

$$
\begin{aligned}
& \text { Xo lá lolo. } \\
& \text { house DEF big } \\
& \text { 'The house is big.' (Dzablu-Kumah 2015: 4) }
\end{aligned}
$$

$$
\begin{aligned}
& \text { Kaz-a gran. } \\
& \text { house-def big } \\
& \text { 'The house is big.' }
\end{aligned}
$$

The word order here is reminiscent of the bipartite demonstrative pronoun structure in French, the house there. The postposed part of the demonstrative structure in French, there, is much more salient than the preposed part the. It is possible that early speakers of FGC only heard or perceived the phonetically salient postposed part of the French structure, là 'there', and consequently re-analysed the right bracket of the demonstrative structure as a definite article (for a more detailed study of alla in FGC, cf. Wiesinger 2015).

The plural form of the definite article is $-y a(n)$.

$$
\begin{array}{llll}
\text { Tifi-ya } & \text { séparé } & \text { ké } & \text { tibonnonm-yan. } \\
\text { girl-PL.DEF } & \text { separate } & \text { com } & \text { boy-PL.DEF }
\end{array}
$$

'The girls and the boys are separated.' (Holder 1988: 7)

The plural form might be best described as a process that draws on both Transfer Type 2 (refunctionalisation) and Transfer Type 3 (morphosyntactic strategy). In the plural definite article, $l a$ is phonetically 
reduced to $a$ and preceded by the third-person subject pronoun they. It is spelt ye and phonetically reduced to $y$. In other words, the plural form ya originated in the structure yé la, lit. 'they there'. Some evidence for this comes from older texts in which the definite plural article is still separated:

$$
\begin{array}{lllllll}
\text { A } & \text { nègue place } & \text { yé } & \text { la, qui dévidé } & \text { Cayenne. } \\
\text { DEM people place } & \text { 3PL DEF REL go } & \text { Cayenne }
\end{array}
$$

'It is the people from the gold sites who go to Cayenne.' (Parépou 1885: 18)

$$
\begin{array}{llllllll}
\text { Nègue Kourou } & \text { yé } & \text { la } & \text { wa } & \text { beau vanté yé cassave. } \\
\text { people Kourou } & \text { 3PL } & \text { DEF } & \text { FUT } & \text { in vain praise } & \text { 3PL cassava } \\
\text { 'The people of Kourou will praise their cassava in vain.' (Parépou 1885: 46) }
\end{array}
$$

While the phonetic material comes from French, the word-order strategy of FGC (second example below) follows the Ewe pattern exhibited in awó 'they there' (first example below):

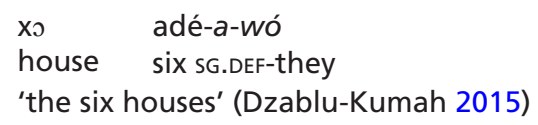

(38)

$$
\begin{aligned}
& \text { si kaz yé-la } \\
& \text { six house 3PL-DEF } \\
& \text { 'the six houses' }
\end{aligned}
$$

In summary, plural marking in FGC exhibits features of both wordorder transfer and refunctionalisation. It is crucial to note here that a pattern such as les arbres ... eux ... là (lit. 'the trees they there') can be found in corpora of informal spoken French. The structure is rare, though, and has a specific pragmatic function. When used, the speaker wants to make sure that the listener can identify an object that can be seen at some distance, along the lines of the trees you can see over there. 
The origin of the form la is not easy to determine as it is virtually identical in French and Ewe. The fact that both FGC and Ewe have an allegro variant $a$ (omitting the initial l-) further complicates matters. The similarity seems to be a case of mere coincidence. The transfer of la from Ewe is supported by the fact that Creole la can be reduced to $a$, which is possible for Ewe la but not for French là. The transfer of là from French is supported by the fact that FGC là does not have the rising tone of Ewe la and is thus closer to the phonic gestalt of French là. Overall, we might want to hypothesise that the convergence of similar forms enhances the possibility that they appear in the creole.

\subsubsection{Demonstrative}

Unlike in French, in FGC there is only one demonstrative, $s a \ldots$, for 'this' and 'that', where sa precedes the noun and - $a$ follows it (cf. French ce...-là), as in:

$$
\begin{array}{lll}
\text { Mo kontan sa liv-a } \\
\text { 1sG like } & \text { DEM } & \text { book-sG.DEM } \\
\text { 'I like this book.' } &
\end{array}
$$

In the plural, the demonstrative is $s a . . .-y a$, as in sa liv-ya ('these books').

$$
\begin{aligned}
& \text { sa timoun-yan } \\
& \text { DEM children-PL.DEM } \\
& \text { 'those children' (CIEL_FR_GF_RADIO) }
\end{aligned}
$$

This syntactic bipartite strategy might be seen as an inheritance from both French and Ewe because French also shows a bracket-construction (41), while Ewe has postposition (42) and bracket-construction (43):

$$
\begin{array}{lll}
\text { ces } & \text { enfants } & \text { là } \\
\text { DEM.PL children } & \text { DEM } \\
\text { 'those children' } &
\end{array}
$$


(42)

$\begin{array}{ll}\text { deví } & \text { siawó } \\ \text { children } & \text { DEM.PL }\end{array}$

'these children' (Dzablu-Kumah 2015: 31)

(43) to devíwó

DEM children PL

'those children (over there)' (Dzablu-Kumah 2015: 31)

The second Ewe example (43), being more deictic in face-to-face interaction in the early years of contact, is likely to be used. If this final assumption is correct, then FGC exhibits a morphosyntactic strategy transfer from Ewe insofar as the plural is marked within the right bracket of the construction, whereas in French, it is marked in the left bracket.

In modern media texts, sa ...-ya can also be found in more complex structures, such as the following:

$$
\begin{aligned}
& \text { sa genre de bèt-ya } \\
& \text { DEM kind of thing-PL.DEF } \\
& \text { 'these kinds of things' (CIEL_FR_GF_RADIO) }
\end{aligned}
$$

It is important to note that $s a \ldots-a$ (and in the same way, sa .. -ya) can be used not only adnominally, but also pronominally, as in the following example:

$$
\begin{aligned}
& \text { Sa-a movè } \\
& \text { DEM-SG.DEF bad } \\
& \text { 'This one is bad.' }
\end{aligned}
$$

In older texts, we find examples like the following:

$$
\begin{aligned}
& \text { Gadé qué oueil, ça la Chinois yé wa tombé. } \\
& \text { Look with eye } \text { DEM DEF Chinese 3PL fut fall } \\
& \text { 'Look around you, those Chinese people, they will fall.' (Parépou 1885: } \\
& \text { 50) }
\end{aligned}
$$

It is important to note that ça is used for animate subjects in CIEL-F in some varieties in both Africa and Canada (Boutin and Gadet 2012). 
If we assume that this use was attested in the early years of contact, there is some inheritance from both French and Ewe here.

\subsubsection{Personal Pronouns}

There are three sets of personal pronouns—subject pronouns, object pronouns and adnominal possessive pronouns - that differ only in the third-person singular (see Table 3.1).

Both FGC and Ewe use the forms of subject (or object) pronouns to express possession, while French does not. Hence, mo can mean 'I', 'me' or 'my'. While the lexical material comes from French, the strategy of using the same form for different types of pronouns seems to be due to transfer from Ewe. These types of syntactic strategy transfer are sometimes analysed as cases of simplification. However, FGC has only a few simplified subsystems, suggesting that the marking of possession is due to transfer from Ewe rather than to simplification of the French subsystem.

As in many other creoles, there is no gender distinction in the third-person singular in FGC: the forms $i, l i, l$ 'and so denote both male and female referents. However, some speakers use misyé and madanm as third-person singular pronouns; these forms seem to grammaticalise in the smaller townships but are rarely used in Cayenne or Kourou in our corpus.

\subsubsection{Possessives}

The possessive adjective in FGC precedes the noun, as illustrated in the following examples:

Table 3.1 Personal pronouns in FGC

\begin{tabular}{llll}
\hline & Subject & Object & Adnominal possessives \\
\hline 1SG & mo & mo & mo \\
$2 S G$ & to/ou & to/ou & to/ou \\
$3 S G$ & i & li $\left(\mathrm{I}^{\prime}\right)$ & so \\
$1 \mathrm{PL}$ & nou & nou & nou \\
$2 \mathrm{PL}$ & zòt & zòt & zòt \\
$3 P L$ & yé & yé & yé \\
\hline
\end{tabular}


(47)

$$
\begin{array}{llll}
\text { mo liv } \quad \text { to } & \text { kaz } \\
\text { POss.1sG book POSs.2sG } & \text { house } \\
\text { 'my book, your house' } &
\end{array}
$$

(48) So kaz-a toujou prop POSS.3sG house-DEF always 'His house is always clean.' (CIEL_FR_GF_RADIO)

(49) Oun gran larivyè ki ka séparé INDF big river REL PROG separate nou péy Lagwiyan di Sirinanm $1 \mathrm{PL}$ country French Guiana from Suriname 'A big river separates French Guiana from Suriname.' (Holder 1988: 7)

(50) A zòt timoun ki la? DEM POSS.2PL child REL there 'Is that your child over there?'

In modern media, the French vòt (<votre) sometimes replaces zòt:

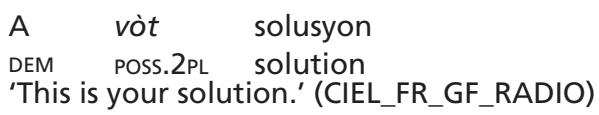

In both French and Ewe, possessive adjectives precede the noun. However, FGC possessive marking is more similar to Ewe. The forms of the possessive pronouns mine, yours, etc. developed in a lexicalisation process that fused two items, namely the possessive adjectives discussed above and a phonetically reduced form of the noun part.

$$
\begin{array}{lll}
\text { mopa } & \text { topa } & \text { sopa } \\
\text { 'mine' } & \text { 'yours' } & \text { 'hers/his' }
\end{array}
$$

In older texts, we find the same construction; however, the fusion has not yet taken place and the elements are still written as two words with 
a meaning that could make the source of the construction transparent (>'for my part', 'as for me'):

$$
\begin{array}{llllll}
\text { Mo } & \text { pa, } & \text { a } & \text { Oyapoc } & \text { mo } & \text { soti. } \\
\text { 1sG } & \text { part } & \text { LOC } & \text { Oyapock } & 1 \mathrm{sg} & \text { come from }
\end{array}
$$

'As for me, I'm coming back from the Oyapock.' (Parépou 1885: 14)

This type of lexicalisation strongly resembles Ewe, where the possessive adjectives nyè, wò, etc. are fused with the noun to 'part'. We would not expect a combined lexicalisation and grammaticalisation process in FGC, as the combination of a possessive adjective followed by the noun part would not be a highly frequent string in everyday French conversation. Hence, the forms of the possessive pronouns mine, yours, etc. are argued to be due to transfer from Ewe.

\subsection{Verb Phrase}

\subsubsection{Introduction}

In the previous section, we provided possible pathways of transfer for individual features of the noun phrase. The nature of the verb phrase in FGC, with its interrelated system of tense, mood and aspect (TMA) markers, requires a more holistic approach, and this section thus proposes a transfer hypothesis after carefully outlining the functional range of each marker. This approach also allows for a discussion of the full TMA system, which has been the cornerstone of debates on creole genesis since Bickerton's controversial work (1981).

\subsubsection{The Zero Marker: Perfective Aspect}

In FGC, the zero marker (in the following, $\varnothing$ ) has to be analysed as a perfective aspect, irrespective of its temporal embedding; by contiguity, $\varnothing$ often has a past-tense reading, but not necessarily. The following examples demonstrate how $\varnothing$ can have past, present and future reference according to genre and context. 
The perfective aspect marker $\varnothing$ has a past time reference, especially in narrative sequences. This use is well known from what may be the first sentence in FGC for which we have a historical record (a wood carving):

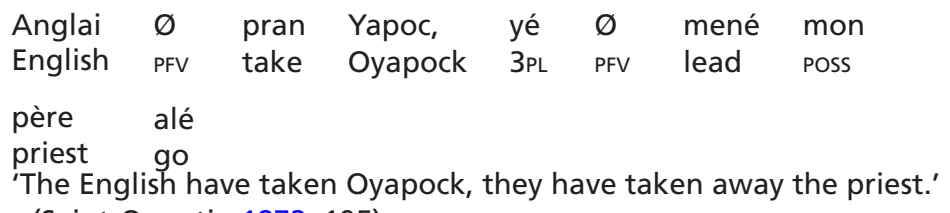

If we examine storytelling, we find long chains of zero-marked verbs. In the following example, we observe that a narrative is given only via bare verb forms:

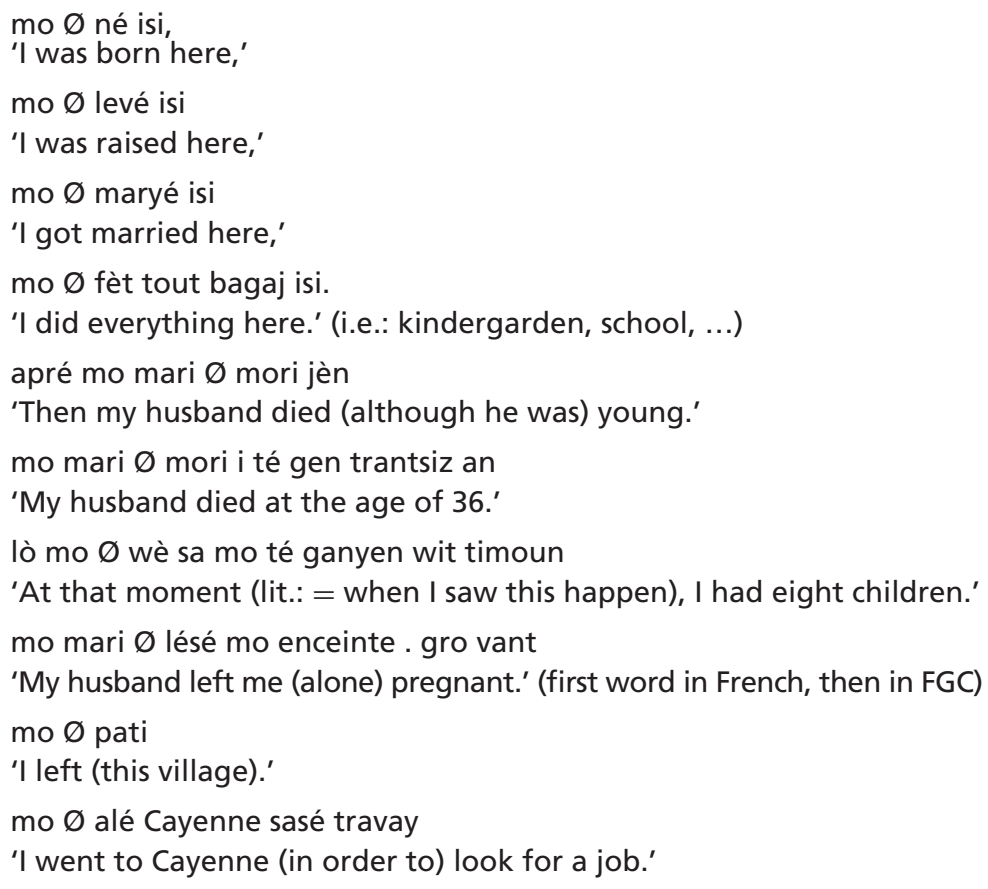

The chain of actions justifies why the narrator, a woman aged 68 at the time of the interview, went to work in Cayenne, thereby leaving the village where she was born. It is important to note that the typical 
grounding of a chain of actions can be lò, 'when', and it is always zeromarked. Corpus examples include the following:

lò to Ø rivé

'when you arrive(d)'

lò to $\varnothing$ pati

'when you leave (left)'

(58)

lò nou $\oslash$ wè sa

'when we see (saw) that'

(59)

lò i $\varnothing$ fè $n$ promenad

'when he goes (went) for a walk'

The second example of storytelling involves explaining field work. Here again, the actual activity in the field and going back home are marked as the salient actions.

(60) Nou bati tou $\varnothing$ proch tou $\varnothing$ proch

'Our field was not far away.'

Trwa jou nou ka alé serklé

'We worked there for three days'

answit jiskan y $\emptyset$ fini.

'until everything was done.'

Épi nou ka désann

'And then we went back (on the third day).'

Bèn lò to $\varnothing$ rivé to $\varnothing$ fè to ben-d-basen.

'When we came back, we had a nice bath.'

To $\varnothing$ lavé, to $\varnothing$ alé pozé to kò.

'We washed ourselves, we had a rest.'

To $\varnothing$ ranjé to kabann,

'We tidied up our belongings,'

épi sayè! Nou té ka viv, oh !

'and then that was it, we lived (well), you see.' 
The actions of cleaning up and having a rest are given as perfective actions, and it is thus not the event structure itself that is or is not objectively (im)perfective; rather, it is the speaker who may subjectively choose an (im)perfective perspective for different parts of her or his narrative reconstruction of the events. This matches perfectly well with the English etymon "aspect" as well as with the original Russian term for aspect, "vid", both of which mean "gaze / the action of looking at something".

The perfective aspect marker $\varnothing$ can have a present time reference or lack temporal reference all together, as in this greeting:

$$
\begin{array}{llll}
\text { Sa } & \varnothing & \text { alé } & \text { byen } \\
\text { 3sG PFV } & \text { go well } & \text { well } \\
\text { 'I am fine.' (Pfänder } & \text { 2000a: 90) }
\end{array}
$$

Here, alé, 'to go', is a verb not of movement (and thus does not mean 'I went'), but of current state ('I am fine'). Similarly, verbs like savoir and trouver have a present reading and do not refer to the dynamic action of learning or searching but instead refer to a state of mind that also expresses a stative meaning:

(62) Oui, mo trouvé ça, réponne Atipa Yes 15G find DEM answer Atipa '"Yes, I think so," said Atipa.' (Parépou 1885: 18)

(63) To savé

2sG know

'You know.' (Parépou 1885: 18)

(64) Mo krè an Bondyé 1sG believe in God 'I believe in God.' 
(65)

$\begin{array}{llllll}\text { Lò } & \text { blangue } & \varnothing & \text { baille } & \text { li } & \text { avance, } \\ \text { When } & \text { white } & \text { PFV } & \text { pay } & \text { 3sG } & \text { advance } \\ \text { yé } & \text { pouvé } & \text { compté } & \text { là-sous } & \text { li } & \\ \text { 3PL } & \text { can } & \text { count } & \text { on } & \text { 3sG } & \end{array}$

'When the whites pay him in advance, they can rely on him.'

(Parépou 1885: 206)

In addition, the zero marker can contextually show a future time reference, especially if the previous sentence is an imperative:

$\begin{array}{lllllll}\text { Ba mo } & \text { dé } & \text { jounen, } & \text { trwa } & \text { jou, } \\ \text { Give 1sG } & \text { two } & \text { days } & \text { three } & \text { days } & \\ \text { mo } \varnothing & \text { sabré } & \text { oun } & \text { ti } & \text { bati } & \text { la. } \\ \text { 1sG PFV } & \text { cut } & \text { DET } & \text { small } & \text { clearing } & \text { DET/LOC }\end{array}$

'Give me two or three days, and I will cut a clearing.'

(Jean-Louis 1987: 295)

$\begin{array}{lllllll}\begin{array}{l}\text { Konpè } \\ \text { brother }\end{array} & \text { Makak, } & \text { Macaque } & \text { oh } & \begin{array}{l}\text { mon } \\ \text { Poss }\end{array} & \begin{array}{l}\text { ami, } \\ \text { friend }\end{array} & \\ \text { ba } & \text { mo } & \text { mo } & \text { palto, } & \text { mo } & \varnothing & \text { alé. } \\ \text { give } & 1 \mathrm{sg} & \text { POss.1sG } & \text { jacket } & 1 \mathrm{sG} & \text { PFV } & \text { go }\end{array}$

'Brother Macaque, oh, my friend, give me my jacket, and I will go.' (Jean-Louis 1987: 437; 444)

The common examples above provide good evidence to prevent misunderstanding zero marking as representing past reference; instead, it is perfective aspect marking, which-by default-may have past reference simply because an action that is presented as being 'perfect' tends to be complete. However, present or future readings are certainly possible, as we have seen, if the speakers want to talk about an action as an action without going into any processrelated details. 


\subsubsection{Ka: Progressive Aspect}

Since its earliest attestations, $k a$ in FGC has mainly been used for progressive aspect.

$$
\begin{array}{lll}
\text { Mo ka } & \text { alé } \\
\text { 1sG PROG } & \text { go } \\
\text { 'I am going.' } &
\end{array}
$$

In the majority of examples, this marker refers to events that take place at the very moment of speech:

$$
\begin{array}{lllll}
\text { Coument, } & \text { to } & \text { ca } & \text { doumandé } & \text { mo, } \\
\text { What } & \text { 2sG } & \text { PROG } & \text { ask } & 1 \mathrm{sG} \\
\text { si } & \text { ça } & \text { vrai, } & \text { réponne } & \text { Atipa. } \\
\text { COND } & \text { DEM } & \text { true } & \text { reply } & \text { Atipa }
\end{array}
$$

'“What, you're asking me if it's true?" replied Atipa.' (Parépou 1885: 20)

This is still true today, as the following two examples illustrate. Whereas with to ka konprann, the speaker asks for some kind of processual understanding, the use of the zero marker ou $\varnothing$ konprann asks for a perfective understanding of what has been exposed so far:

\begin{tabular}{llllllll} 
(70) Dé & timadanm & la nou & $k^{\prime}$ alé & bladyé & ké & yé \\
DET & girl & LOC 1 PL & PROG.go & have fun & COM & 3PL \\
anfen & voyé & blag! & & & & \\
so & send & \multicolumn{2}{c}{ joke }
\end{tabular}

'Girls are there; we have fun with them and make a lot of jokes.'
(71) To ka konprann 2sG PROG understand 'You understand.'


(72)

$$
\begin{aligned}
& \text { Ou komprann? } \\
& \text { 2PL understand } \\
& \text { 'Do you understand?' }
\end{aligned}
$$

In Martinican Creole (MAC), the imperfective marker $K A$ may express progressivity, but mostly expresses habitual or iterative meaning (Damoiseau 1984: 23).

$$
\begin{array}{llllll}
\text { Tou lé } & \text { dimanch } \quad \mathrm{i} & k a & \text { manjé } & \text { pwason } \\
\text { every } & \text { Sunday } & \text { 3sG } & \text { IPVF } & \text { eat } & \text { fish } \\
\text { 'He eats fish every Sunday.' (Damoiseau 1984: } & 22)
\end{array}
$$

MAC also differs from FGC in that it uses $k a$ mainly with present reference and requires combination with the past marker té to form té $k a$ to indicate past reference. The té can be dropped only once the speaker has established that the context is not in the present. FGC, on the other hand, can use $k a$ with past reference without a past marker. Stative verbs in MAC rarely combine with $k a$ and do so only to express inchoative (e.g. getting angry) as in (74) or habitual meaning (e.g. usually being angry). The core meaning of imperfective aspect, i.e. progressivity, is blocked by stative verbs in MAC:

$\begin{array}{llll}\text { Timanmay } & \text { la } & k a & \text { bèl } \\ \text { child } & \text { DEF } & \text { INCH } & \text { beautiful }\end{array}$

'That child is starting to become beautiful.' (Damoiseau 1979: 165)

In FGC, all verbs can be combined with the imperfective marker. If so-called stative verbs are combined with $k a$, the default meaning is progressivity. The main function of $k a$ found in FGC data is to demonstrate the progressivity of an action, which is preceded by a verb of perception (typically visual), as in the first of the examples below: 
(75)

Mo manman! La
POSS mother
'Gosh! There, he spots the other group and sees people.'

In the above example, the stative, denominal verb kolè $(<$ la colère "anger") is used with the imperfective particle. It is clearly not intended as an iteration or habituality here, but as progressivity. It is important to note that the sense here is not inchoative: The addressee is not about to be or becoming angry, but is currently angry.

In short, $k a$ in FGC has progressive meaning and refers to an event that happens at the moment of speaking and before the speaker's or listener's eyes. As both dynamic and stative verbs are used in this context, we shall take a closer look at these different uses and compare expressions with dynamic and stative verbs.

\subsubsection{Stative vs. Dynamic Verbs}

One parallel between FGC and other lexically French creoles is that the same aspect marker may convey different meanings according to whether it marks stative or dynamic verbs. However, FGC behaves differently in that it is not limited to dynamic verbs, but is productive 
for all kinds of verbs or verboids (Ludwig 1996), as this section will show. This difference is significant because it indicates a greater convergence between FGC and languages of the Gbe family, which would be very much in line with the findings of both historical Chap. 2 and the findings in the previous (and following) linguistic sections of Chap. 3.

In FGC, verbs based on adjectives denoting the characteristics of objects (dry, full, white, fat, bloated) can be combined with the imperfective marker $k a$ to express processual meanings, referring to things that are becoming dry, full, white, fat, bloated, etc. In contrast, zero marking would express "states", referring to things that are dry, full, white, etc.

$\begin{array}{lllll}\begin{array}{l}\text { Toupannan } \\ \text { While }\end{array} & \begin{array}{l}\text { lenj-a } \\ \text { clothes-DET }\end{array} & \begin{array}{l}k a \\ \text { PROG }\end{array} & \begin{array}{l}\text { sèk dry } \\ \text { dry on }\end{array} & \begin{array}{l}\text { on } \\ \text { on }\end{array} \\ \text { timoun-yan } & k a & \text { tranpé } & \text { annan } \\ \text { 'children-det } & \text { PROG } & \text { soak } & \text { in } & \text { dilo-a } \\ \text { water-DET }\end{array}$

'While the clothes are drying on the grass, the children go into the water.'

(Schlupp 1997: 73)

In the next example, which refers to the preparation of manioc, blan ("to be white") is combined with $k a$ as a process:

(77) To ka lavé l' byen prop pis l ka blan. 2sG PROG wash.3sG well clean more 3sg PROG white 'You wash it nice and clean because it becomes white [as you peel it].'

A similar example is the use of plen ('to be full') in one of Tchang's transcribed fairy tales:

$$
\begin{aligned}
& \begin{array}{llll}
\text { Mé a } & \text { 'n } & \text { ti } & \text { bous... } \\
\text { Look it's }^{\text {DET }} & \text { small } & \text { purse }
\end{array} \\
& \begin{array}{llllll}
\text { Toutan i } & \varnothing & \text { plen } & \mathrm{i} & \varnothing & \text { plen! }
\end{array} \\
& \text { Always 3sg PFV full 3sg PFV full }
\end{aligned}
$$


(79)

$\begin{array}{lllllll}\text { Lò } & \text { wou } & \text { tire } & \text { tout } & \text { soumaké } & \mathrm{i} \\ \text { when } & \text { 2PL } & \text { draw } & \text { all } & \text { money } & 3 \mathrm{sG} & \\ \varnothing & \text { ganyen } & \text { annan, } & \text { kou } & \text { wou } & & \\ \text { PFV } & \text { have } & \text { inside } & \text { when } & 2 \mathrm{PL} & & \\ \text { fin } & \text { tire } & \mathrm{I}^{\prime} & \mathrm{i} & \text { ka } & \text { plen } & \text { ankò } \\ \text { finish } & \text { draw } & 3 \mathrm{SG} & 3 \mathrm{sG} & \text { PROG } & \text { fill } & \text { again }\end{array}$

'When you take out all the money that was inside, when you've taken it all out, it fills back up again.'

(80) Wou tire ou dépasé tout soumaké i $\varnothing$ ganyen, 2PL draw or spend all money 3sG PFV have 'You take out all the money that's inside and spend it.'

(81) Lò wou fin tire dernyé-a i

Then 2PL finish draw last-DET 3SG

$\varnothing \quad$ rouplen ankò!

PFV refill again

'As soon as you've taken out the last coins, it's already full again!'

(Guy Tchang 1988: 154.1)

Here, we have a purse that displays the rather nice characteristic (state) of always being full (see toutan i plen: "it is always full"). In the second line, the purse appears with $k a$, indicating the process of filling: "It fills back up again". In the final line, it is described as full again (state).

The same logic holds for stative verbs that indicate a person's mood as opposed to their character. While to $\varnothing$ fou would be used to address someone considered permantently insane, to ka fou refers to a temporary state as illustrated in the following excerpt:

\begin{tabular}{|c|c|c|c|c|c|c|c|c|}
\hline $\begin{array}{l}\text { Alò } \\
\text { So }\end{array}$ & $\begin{array}{l}\text { to } \\
2 s G\end{array}$ & $\begin{array}{l}k a \\
\text { PROG }\end{array}$ & $\begin{array}{l}\text { fou, } \\
\text { mad }\end{array}$ & $\begin{array}{l}\text { bagaj } \\
\text { thing }\end{array}$ & $\begin{array}{l}k a \\
\text { PROG }\end{array}$ & $\begin{array}{l}\text { pasé } \\
\text { happen }\end{array}$ & $\begin{array}{l}\text { a } \\
\text { in }\end{array}$ & \\
\hline $\begin{array}{l}\text { to } \\
\text { POss.2sG }\end{array}$ & $\begin{array}{l}\text { tèt, } \\
\text { head }\end{array}$ & & $\begin{array}{l}\text { to } \\
2 s G\end{array}$ & $\begin{array}{l}k a \\
\text { PROG }\end{array}$ & $\begin{array}{l}\text { ri } \\
\text { laugh }\end{array}$ & $\begin{array}{l}\text { pou } \\
\text { for }\end{array}$ & $\begin{array}{l}\text { bon } \\
\text { good }\end{array}$ & $\begin{array}{l}\text { kyò } \\
\text { heart }\end{array}$ \\
\hline
\end{tabular}


In the extract below from a story about a parrot that befriends a lonely boy (Lohier 1960: 196/334), we find the stative verb tris ('to be sad') both with (87) and without $k a(84)$. The narrator uses the zeromarked form to establish that the boy is characteristically sad. To show that the parrot views the sadness as a temporary illness that strikes each day, the narrator marks the same verb with $k a$ :

$\begin{array}{llllll}\begin{array}{l}\text { Annan } \\ \text { In }\end{array} & \begin{array}{l}\text { lékol-a } \\ \text { school-DET }\end{array} & \begin{array}{l}\text { gen } \\ \text { have }\end{array} & \begin{array}{l}\text { roun } \\ \text { DET }\end{array} & \begin{array}{l}\text { gran } \\ \text { big }\end{array} & \begin{array}{l}\text { lakou } \\ \text { yard }\end{array} \\ \text { koté } & \text { timoun-yan } & \varnothing & \text { kontan } & \text { anmizé } & \\ \text { where } & \text { child-DET } & \text { PFV } & \text { love } & \text { enjoy } & \end{array}$

'At school, there is a large play area, where the children like to play.'

(84) $\mathrm{Li}$ gen roun timoun so tchò toujou $\varnothing$ tris 3sG have DET child POss.3sG heart always PFV be sad 'There is one child whose heart is always sad'

(85) Pars $\mathrm{i}$ pa gen $\mathrm{ti}$ boug $\mathrm{ki}$

because 3SG NEG have small person REL

lé jwé ké li

want play with $3 \mathrm{sg}$

'because there are no children who want to play with him.'

(86) Jako-a rete i di: “Non, a pou

Parrot-Def stay 3sg say no 3sg for

mo trapé roun rémèd pou mo kolèg-a.

1SG catch DET cure for POSS friend-DET

'The parrot says, "No, I have to cure my friend."'

(87) I ka tris tro bokou. 3sG PROG sad too much 'He's so sad.' 
(88)

$\begin{array}{llllllll}\text { A } & \text { pou } & \text { mo } & \text { fè } & \text { l'kontré } & \text { ké } & \text { roun } & \text { moun } \\ \text { 3sG } & \text { for } & 1 \mathrm{sG} & \text { make } & 3 \mathrm{sG}-\mathrm{meet} & \text { com } & \text { INDF } & \text { person } \\ \text { ka } & & \text { ari, } & \text { pou } & \text { vé } & \text { géri } & \text { li. } & \\ \text { PROG } & & \text { laugh } & \text { for } & \text { want } & \text { cure } & \text { 3sG } & \end{array}$

'He has to meet someone who is happy and who is going to cure him.'

A similar interpretation holds for the verb krè, "to believe". In our corpora, we usually find this verb with $\varnothing$-marking. However, if believing is somehow momentary and linked to an ongoing action, it is marked by $k a$. Here, the speaker observes someone being saved from death, and in this very moment, he believes in God:

$$
\begin{array}{lllllll}
\text { Mo } k a & \text { we } & \text { sa, } & \text { mo } & k a & \text { krè } & \text { an bondyé } \\
\text { 1sG PROG see that, } & 1 \mathrm{sG} & \text { PROG } & \text { believe } & \text { in God } \\
\text { 'I observe that I believe in God' } & & &
\end{array}
$$

In FGC, even seemingly objective facts, such as a tree that is tall or a house that is far away, can be combined with the imperfective marker if the tree appears to grow taller upon climbing it or the house appears to become farther away upon walking towards it. The following examples should clearly be interpreted progressively:

$\begin{array}{lllllll}\text { Ti } & \text { boug-a } & \varnothing & \text { monté } & \text { i } & \varnothing & \text { monté, } \\ \text { Little } & \text { person-DET } & \text { PFV } & \text { climb } & 3 s G & \text { PFV } & \text { climb } \\ \text { i } & \varnothing & \text { monté } & & & & \\ 3 \mathrm{sG} & \text { PFV } & \text { climb } & & & & \end{array}$

'The guy climbed and climbed and climbed...'

(91) Amizu ti boug-a ka monté,

More little person-DET PROG climb

amizu pyébwa ka rot

more tree PROG high

'...(but) the higher he climbed, the higher the tree grew.' 
This is obviously more processual: the higher the hero climbs (amizu ti boug-a ka monté), the higher the tree appears to grow ( $k a$ rot 'grows in height'; literally "it highs") (Tchang 1988: 54.2; cf. Migge 2000: 216217 for similar observations, comparing Ndyuka and Gbe).

$$
\begin{array}{llll}
\text { Koté } & \text { Francine i } & \varnothing & \text { Iwen } \\
\text { side } & \text { Francine 3sG } & \text { PFV } & \text { be far } \\
\text { 'Francine lives far away.' } & &
\end{array}
$$

$$
\begin{array}{llllll}
\text { pou alé } & \text { koté } & \text { Francine } & \text { i } & k a & \text { Iwen } \\
\text { in order to go side } & \text { Francine } & \text { 3sG } & \text { PROG } & \text { be far } \\
\text { 'It's a long way to go to Francine's.' } & & &
\end{array}
$$

While the distance in (92) is given without reference to the context, the action is emphasised in (93), which can be paraphrased as follows: 'From the place you find yourself in at the moment of speaking, you have to walk for a long time in order to get to Francine's.

In conclusion, our analysis confirms Saint-Jacques Fauquenoy's (1972) observation that the distinction between stative and dynamic verbs may be crucial in MAC (and in other Caribbean creoles), but not in FGC. All verbs, including de-adjectival and denominal verbs (which are often called stative), can express progressive meanings, just as dynamic verbs do. This is very much in line with the findings presented in Migge (2000) and Migge and Winford (2007) on Surinamese Creoles.

Finally, in a usage-based linguistics framework, the aspectual perspectives of stative and dynamic verbs can be explained by experience: the default use of actions is in narratives, when they have happened; states are by default considered non-perfective.

\subsubsection{Completive Aspect: Fin (and Kaba)}

If a speaker wants to insist that an action has in fact been completed, he/she can use the marker fin or kaba. 
(94) Lò yé fin koupé yé bati...
When 3PL finish cut $3 \mathrm{PL}$ slash
'When they had finished cutting down trees...'

(95) $\mathrm{Hm}$ mè to kontan to bati fin planté. $\mathrm{Hm}$ but 2sG like 2sG slash finish plant 'yes, you were happy that your land had been planted.'

Fin has been said to derive from French finir de, which has similar functions in several varieties of French. However, in standard French, it tends more towards the lexical meaning of 'to finish', whereas in FGC, fin is clearly functionalised and thus part of core grammar (completive aspect).

In the nineteenth-century novel Atipa, kaba, spelt caba, is best translated by 'already', as all the following examples illustrate (we skip the glosses in the following examples because only the global meaning of the often complex sentence is what interests us here):

(96) Et to meinme a dé faim mo faim. Mo vente ca fait kioume caba. 'As for me I am dying of hunger. My belly is already rumbling.'

(Parépou 1885: 38)

(97) Mouché Chapy fait divin caba à Kourou et bon divin encò.

'Mr. Chapy has already made some wine in Kourou wine of very good quality.' (Parépou 1885: 66)

(98) Sénato zòte ca doumandé la; blangue ca peyé oune moune caba qui pou ca fait engin ou crai yé wa wlé peyé dé pou bon kiò conça? 'You're calling for a new Senator! The whites are already paying for one who doesn't do anything; do you think they will pay for two just like that for nothing?' (Parépou 1885: 82)

(99) Ça qui allé la danbois qué Apatou la a pas soumaqué li dépensé pou bon kiò? Ça li dit mouché Louprie palé di ça caba.

'The man who went in to the forest with Apatou, didn't he spend money in vain? Mr Le Prieur had already talked about what the man had said.' (Parépou 1885: 174) 
Twentieth-century uses of kaba show a growing tendency to express completive aspect. The contextual reading is often that of reassurance:

$$
\begin{aligned}
& \text { I vini kaba } \\
& \text { 3sg come compL } \\
& \text { 'He did come.' ('He surely was there.') }
\end{aligned}
$$

$$
\begin{array}{llll}
\text { I té vini kaba } \\
\text { 3sG PST come compL } \\
\text { 'He had come.' ('for sure') }
\end{array}
$$

Kaba is a postposed marker derived from Portuguese. According to Horth (1948), it was used with the meaning of "already" and/or "completed action" in vernacular or pidgin Portuguese on the Brazilian border with French Guiana.

The postposed aspect marker-kaba is also documented in Papiamento and classified as a perfect marker (Andersen 1990) or a pluperfect marker (Maurer 1998). Kaba has its possible sources in Portuguese:

Ele acaba de chegar em casa.

'He has just arrived home.'

Os estudantes acabam de fazer o exame final. 'The students have just written their final exam.'

Note that $k a b a$ is found with a similar or identical meaning in other creoles with a Portuguese lexical base, Negerhollands (which has mainly a Dutch lexical base), as well as in Sranan (which has mainly an English lexical base; cf. Stolz 1987: 300). Winford and Migge have argued in a very similar vein "Completive kaba in the Surinamese creoles is modeled after the VP-final marker of completion common to both Eastern and Western Gbe languages" (2007: 14). 


\subsubsection{Té, the Only Tense Marker in FGC}

Having considered several options of aspect marking in FGC, we now present the only tense marker in this language, té. In FGC past tense is expressed by the marker té, as in the following examples:

(104) Timoun-yan pa té gen tan jwè
children-DEF.PL NEG PST have time play
'The children had no time to play.'

(105) Mo té fè mo granlajan

1SG PST make poss big-money

'I have made a lot of money.'

(106) Mo té gen oun kopen

1SG PST have INDF friend

'I had a friend.'

(107) Gas té antré

gas PST get in

'It was filled with air.'

(108) Alò nou té alé a so kaz so we PST go at poss home 'So we went to his house.'

In our corpus (cf. Appendix), the story "Nearly Drowned" focuses on a boat trip home from a friend's place. The narrator sets the scene by providing background information. To indicate that the journey to the friend's place lies prior to the story's main narrative, the speaker marks verbs with the past-tense marker té. 
(109)

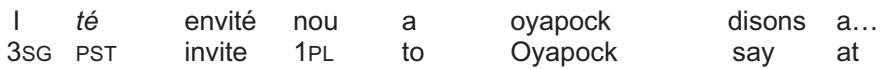

'He had invited us to the Oyapock river, let's say at ...'

$\begin{array}{llll}\text { a di } & \text { minut di } & \text { saint georges } \\ \text { at ten } & \text { minute } & \text { from } & \text { Saint-Georges } \\ \text { 'ten minutes (distance) } & \text { from Saint-Georges,' }\end{array}$

mais de l'autre côté de la frontière...

but on the other side of the border

'but on the other side of the border'

... en kannon.

....by boat

'...on a boat.'

Nou té alé ké oun kopen

$1 \mathrm{PL}$ PST go with INDF friend

'n kopen Pascal.

INDF friend Pascal

'We went (there), a friend (and I), a friend (named) Pascal.'

Pascal euh a té oun postier...

Pascal INT PST DET postman

'Pascal, well... he was a postman...'

... ki té ka travay à la poste.

...REL PST PROG work at the Post Office

'...who used to work at the post office.'

Déjà pati

Already leave

'He had already left (Saint-Georges).'

alò nou té alé a so kaz.

so 1PL PST go to poss house

'So we went to his house.'

The results from the corpus data are quite intriguing because in most, if not all other French-based Caribbean creoles, the marker té is labelled by fellow researchers as indicative of past-before-past actions. 
To confirm that our corpus findings for FGC indicate past (and only rarely past-before-past), we ran an elicitation test, asking speakers both of FGC and MAC to translate sentences. While Martinican informants translated the French pluperfect with té, the French Guianese informants translated the pluperfect with $\varnothing$, as illustrated below.

$$
\begin{array}{llllll}
\text { Mo frè } \varnothing \quad \text { alé lave larivyè ayè } & \text { bonma(n)ten. } \\
\text { my brother PFV go wash river yesterday } & \text { morning } \\
\text { 'Yesterday morning, my brother went swimming.' } &
\end{array}
$$

$$
\begin{array}{lllllllll}
\text { Mè } & \text { li } & \varnothing & \text { manjé } & \text { anvan. } & \text { Alò } & \text { i } & \text { pa } & \text { té } \\
\text { But } & \text { 3sG } & \text { PFV } & \text { eat } & \text { before } & \text { so } & \text { 3sG } & \text { NEG } & \text { PST } \\
\text { (pou)vé } & \text { najé. } & & & & & & \\
\text { can } & \text { swim }
\end{array}
$$

In the second line of the following example, té in pa té ge is necessary to disambiguate between a reading in which the speaker refers to a present situation and one in which the reference is to the past. Both readings would be possible if zero marking were used instead of té.

$$
\begin{aligned}
& \text { Mo di piti tout k'alé Kayenn aprézan. } \\
& \text { 1sG say youth all IPFV.go Cayenne now } \\
& \text { 'I said that the boys are all going to Cayenne now.' }
\end{aligned}
$$

$\begin{array}{lllll}\text { I } & \text { pa } & \text { gen } & \text { sa } & \text { isi } \\ \text { 3SG } & \text { NEG } & \text { have } & \text { DEM here }\end{array}$

'There isn't anything like that here.'

(113) Pa té gen vrè aprézan timoun-yan viré NEG té have real now children-DETPL return mé sa épok i doumandé but DEM time 3sG ask 'There really wasn't anything. Now, the children are coming back (to the village), but at that time, they weren't sure.' 
If ambiguity between a present- and a past-tense reading is excluded (for example, when the surrounding discourse explicitly recalls past events), té does not appear. Interestingly, most of the uses of té in narratives do not refer to events within the story itself, but are instead meant as a type of comment on the story as a whole. This is true for the example above and also holds true for the following example:

$$
\text { Mo déja té wè bagaj wi pou mo ti laj }
$$
1sG already PST see thing yes for POSs.15G small age 'I had already seen many things, you know, in spite of my young age.'

$T e ́$ does occur sometimes if the narrator wants to situate the narrated events in time, as in the following excerpts:

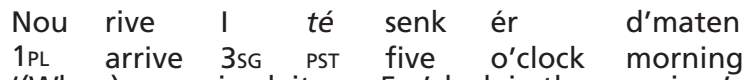

'(When) we arrived, it was 5 o'clock in the morning.'

$$
\begin{aligned}
& \text { Lè nou rivé nou alé dronmi } \\
& \text { when } 1 \mathrm{PL} \text { arrive } 1 \mathrm{PL} \text { go sleep } \\
& \text { i té senkèr/ zizèr d'maten } \\
& \text { 3sG PST five o'clock six o'clock morning }
\end{aligned}
$$

The same usage can be found in school books (e.g. Holder 1988) and on the radio, as in the following examples:

$$
\begin{aligned}
& \text { Tipolo té gen dizan } \\
& \text { Tipolo PST have ten.year } \\
& \text { 'Tipolo was ten years old.' (Holder 1988: 9) }
\end{aligned}
$$

(118) Mo té gen patché fanm

1SG PST have a lot woman

'I had a lot of women.' (CIEL_FR_GF_RADIO) 


$\begin{array}{llll}\text { A } & \text { té } & \text { mo } & \text { lavi } \\ \text { Dem PST } & \text { POSS } & \text { life } & \\ \text { 'This was } & \text { my life.' (CIEL_FR_GF_RADIO) }\end{array}$

TMA particles may be combined. For example, té $+k a$ marks past progressive tense/aspect:

$$
\begin{array}{lllll}
\text { Mo té } & \text { ka } & \text { pale } & \text { ké } & \text { yé } \\
\text { 1SG PST } & \text { PROG } & \text { talk } & \text { COM } & \text { 3PL } \\
\text { 'I was talking to them.' } &
\end{array}
$$

Adverbs may be inserted between the two particles:

$\begin{array}{lllll}\text { Misyé té } \quad \text { souvan } \quad k a & \text { vini } & \text { isi-a } \\ \text { He PST often PROG } & & \text { here- DEF } \\ \text { 'He often came to our place.' } & & \end{array}$

Our investigation of té finds that the particle is used mostly to mark a shift in narrative structure rather than in tense. In this sense, it does not behave like the tense-focused marker té in Antillean Creoles.

\subsubsection{Tense and/or Mood: The Markers Ké and Wa}

Modern FGC usually employs $k a$ or ké to express future actions, although $\varnothing$ is sometimes used. The case is similar in Martinique, although variants of ké also need to be examined (kèy, kay). In the early years of its existence, FGC had a marker wa that is no longer attested to today: Saint-Quentin's 1872 grammar states that wa was a future marker (1872: 133), and Horth says that wa was the archaic form of ké (1948: 28). In nineteenth-century texts, the two markers coexisted, wa being more frequently used. Wa expresses an "uncertain" future (e.g. i wa manjé, 'he will eat') in contrast with the "certain" future (e.g. i ké manjé, 'he is going to eat'). Preceded by té, wa expresses irrealis: $i$ té wa manjé, 'he would eat' or 'he would have eaten'. 
(122)

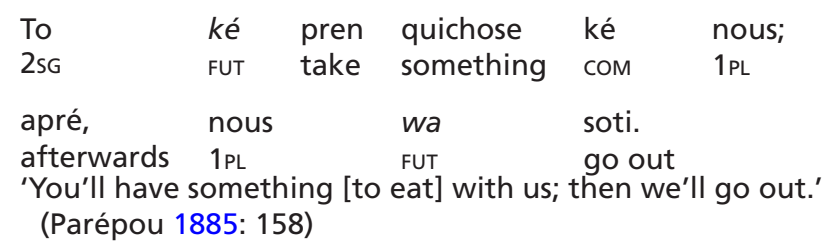

(123)

Nous wa mangé tout lé dé. We FUT eat both DEF two 'The two of us are going to eat (together).' (Parépou 1885: 44)

$K e ́$ did not emerge until more than a century after the development of FGC. Its origin and evolution are clearly shown in nineteenth-century FGC texts: An 1848 proclamation uses kalle and ké (Sournia 1976), and SaintQuentin (1872) uses ké, k'é and k'alé. These variations show the marker ka preceding ale "to go". Ka must therefore have developed before ké.

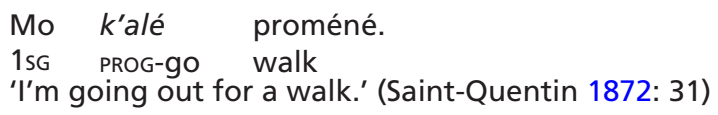

In FGC, ké expresses a so-called certain future while $k a$ expresses a less certain future.

$$
\begin{aligned}
& \text { Épi nou ké alé enstalé St. Louis } \\
& \text { Then 2PL FUT go stay St. Louis } \\
& \text { 'Then we will stay in St. Louis.' (Holder 1988: 7) }
\end{aligned}
$$

To ké byen anmizé to ké wè! 2sG FUT well enjoy 2sG FUT see

'You'll have lots of fun; you will see!' (Holder 1988: 6)

$$
\begin{aligned}
& \text { To pé ké pran kou } \\
& \text { 2sG can FUT take stroke } \\
& \text { 'You might suffer.' (CIEL_FR_GF_RADIO) }
\end{aligned}
$$




\begin{tabular}{|c|c|c|c|c|c|c|c|}
\hline A & mo & ki & ké & gen & to & & \\
\hline DEM & $1 \mathrm{sg}$ & REL & FUT & have & $2 s G$ & & \\
\hline mo & ka & di & mo & ké & mannyen & to & $\mathrm{mo}$ \\
\hline $1 \mathrm{sg}$ & PROG & say & $1 \mathrm{sG}$ & FUT & thrash & $2 s \mathrm{~s}$ & $1 \mathrm{sg}$ \\
\hline
\end{tabular}

'I am the one who will defeat you, I declare that I'll thrash you.'

FGC uses $k a$ to mark scepticism as in the following example:

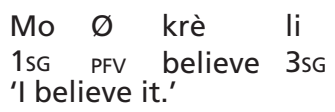

$$
\begin{aligned}
& \text { Mo ka krè li } \\
& \text { 1SG PROG believe 3sG } \\
& \text { 'I sort of believe it.' }
\end{aligned}
$$

How can we explain this assertive meaning of perfective zero marking and of future ké vs. the assertive meaning of progressive $k a$ ? One of the main characteristics of the imperfective (progressive) aspect is that it does not provide any information about the beginning or the endpoint of an activity or event. It has been claimed that the lack of information, particularly regarding the endpoint of an activity, leads to an affinity for the imperfective aspect for non-assertive meanings because it is not possible to be sure that an activity or an event took place if we do not know if, when, or how it was completed. This may explain why $k a$ in FGC is both progressive and non-assertive, whereas it can express both the present tense and an assertive future in MAC. In this case, activities that express present tense relevance are thought of as having already occurred and thus contribute to the expectation that they will indeed take place.

\subsubsection{Aspect in FGC: A Case of Functional Transfer?}

In conclusion, in the previous sections on the verb phrase, we found a strong emphasis on aspect in French Guianese Creole. Except for the 
marker té, which is most often used in combination with the imperfective aspect marker $k a$ to signify the past progressive or past imperfective, all other markers express aspectual meanings only ( $\varnothing, k a b a$, and $f i n)$ or have a combined tense-mood-aspect range of functions ( $w a$ and $k e ́$ ). Quantitative analysis supports these findings: more than $87 \%$ of all verb forms in the 60 hours of the rainforest recordings are marked as perfective or imperfective. The dominant category in FGC is clearly aspect, not tense.

French has provided most of the forms of the FGC verb phrase, but it cannot be the origin of the system's aspectual focus. The history in Chapter 2 revealed the importance of Gbe languages in the creation of the creole, and this section has demonstrated clear links between the FGC verb phrase and that of the aspectually oriented Gbe systems (cf. e.g. Dzablu-Kumah 2015: 51ff. for Ewe and Akoha 2010: 100ff. for Fon). We can thus speak of a category transfer from Ewe to the nascent FGC; aspect is a marginally grammaticalised category in French but has become a core category in FGC, being expressed obligatorily in almost all utterances. In addition, the markers used within constructions expressing aspect seem to be refunctionalisations of French forms (as seen in Sect. 3.5.).

The question of whether syntactic strategy transfer was also involved in the process is more complex and requires the examination of three characteristics. First, the syntactic strategy of combining unchangeable verb stems with monomorphemic separate markers and mono- or disyllabic markers that can be combined is absolutely parallel between FGC (first and third examples) and Ewe (second and fourth examples):

Mo alé kaba

1sG go compL

'I have gone.'

Mè -yì vò

1sG-go COMPL

'I have gone away.' (Pasch 1995: 46)

Mo ké alé

1sG FUT go

'I will go.' 
'I will go.' (Pasch 1995: 43)

Second, there is no morphologically marked verb class in FGC or Gbe languages like Ewe. It might be preferable to speak of verboids rather than of verbs in FGC (cf. Ludwig 1996 for Guadeloupe). FGC gran and Ewe kJ mean 'tall' (ADJ) or 'to be tall' (V), depending on the context.

Third, if the predicate in an utterance behaves more like a verb than an adjective, its zero form denotes the perfective aspect both in FGC and in Ewe:

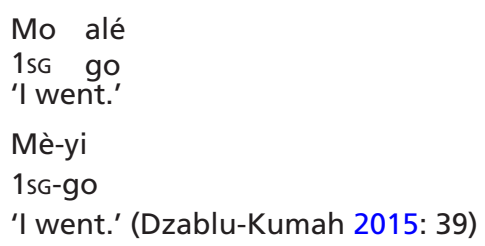

However, if the predicate behaves more like an adjective, the zero form denotes the imperfective aspect (Dzablu-Kumah 2015: 51):

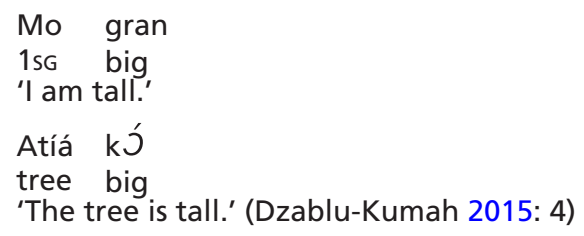

These three characteristics provide evidence for a possible syntactic strategy transfer from Ewe, although word order raises a problematic point because unlike in FGC, most Ewe aspect markers are postverbal (Ameka 1991; Pasch 1995; Dzablu-Kumah 2015). However, there seems to be clear constraint not to distort French word order or, in Andersen's (1989) words, to find some place to transfer things to (cf. Sect. 3.4). In addition, we might want to look more closely at what the (L1, L2, L3) speakers of Gbe languages in French Guiana could identify 
as the imperfective aspect in their own language (the perfective aspect being unmarked, as we saw earlier). We may consider the following two examples from Pasch:

$\begin{array}{llll}\text { Dàdi } & \text { lá } & \text { lè } & \text { tsìtsì-ḿ } \\ \text { cat } & \text { DEF } & \text { PROG } & \text { grow-PROG }\end{array}$

'The cat is making itself appear bigger right now.' (Pasch 1995: 44 for Ewe)

K. lè tó

K. PROG go-out

'K. is on his way downtown [going out].' (Pasch 1995: 44, cf. BoleRichard 1983: 156 for Gẽ)

Here, imperfective (or progressive) aspect is not necessarily expressed only by a single morpheme (postposed $\left.-m^{\prime}\right)$, but sometimes additionally by reduplication (tsitsi, lit. 'grow-grow'). Furthermore, not every Gbe language uses reduplication or a postposed marker, suggesting that multilingual speakers of Gbe languages are not unduly disturbed by the positional flexibility of markers. Finally, the preposed progressive marker lè, considered an auxiliary in some grammars, is always present, even if it is the only marker (cf. Bolé-Richard 1983: 156 for Gê), which means it is the most phonetically salient part of the construction. Lè is invariable and is translated by Dzablu-Kumah as "to be somewhere", a meaning that is a typical source of progressive aspect markers in grammaticalisation chains (cf. Heine and Kuteva 2002: 97).

The characteristics examined above provide evidence of syntactic strategy transfer from Ewe to FGC. They also prove that when considering what speakers might perceive as a possible candidate for a construction, it is important to look at not just spoken varieties of Romance languages (French and Portuguese), but also spoken varieties of the Gbe family (Ewe, Gê, Fon, etc.).

The forms used in FGC to express aspect and tense seem to all be of French (or Portuguese) origin. However, it is more difficult than in Sects. 3.2 (noun phrase) and 3.4 (sentence structure) to determine the exact source of the tense and aspect markers that have led to functionalisation or, more often, to refunctionalisation in FGC. While things are quite clear for fin $(<$ finir de), ké $(k a+$ aller, infinitive and/or participle 
form of 'to go') and $w a$ (<va, third-person singular of 'to go'), the origin of $k a b a, k a$ and té needs to be examined more closely in future research.

If we assume a similar development for the obsolete FGC future marker wa (> French va 3SG), we might want to hypothesise that the French 3SG était, 'was', could have been a source for the FGC marker té. We might also take French 1/2SG and 3PL (étais, 'was', and étaient, 'were') and maybe even the past participle été ('been') into account as convergent sources since they may have sounded similar in the varieties of French spoken during the early years of FGC's development. We would then have another (slightly more complex) case of refunctionalisation via the extension of one or several forms of a morphosyntactic paradigm into the only marker of past-tense reference (for all verbs, all persons, singular and plural). The source of the imperfective marker $k a$ might be the most hypothetical case, and we would assume an origin of the kind attested to today, for example, on the Caribbean island of Saint-Barthélemy, namely il n'est qu'à faire, 's/he is doing'; however, this hypothesis clearly needs further research.

In conclusion, we have found strong emphasis on aspect in FGC in the VP section of this study. This emphasis is not explained by French, even if we concede that spoken French may have more aspect marking than written French, but it is explained by Ewe both historically (Chap. 2) and grammatically (Sect. 3.3). Our explanation of how the system evolved from Ewe to FGC is shown in the successful testing of the hypothesis of transfer (here, category and strategy transfers).

\subsubsection{Modality: Can and Must}

In FGC, deontic modality (i.e. obligation) is expressed by fo (> il faut (faire), an impersonal form of obligation, 'it has to be (done)') and bezwen (> French avoir besoin, 'to need').

$\begin{array}{llllll}\text { Aswè-a } & \text { nèg } & \text { fo } & \text { to } & \text { ba } & I^{\prime} \\ \text { tonight-DEF } & \text { man } & \text { have to } & \text { 2sG } & \text { give } & 3 s G \\ \text { oun } & \text { bon } & \text { ti } & \text { bagay... } & & \\ \text { INDF } & \text { good } & \text { little } & \text { thing } & & \end{array}$

'Tonight, my friend, you will have to give him something...' 
(139)

Nou bezwen jité bwa

we need cut wood

'We have to cut the trees.'

(140)

Démen yé ké bezwen yé...

tomorrow 3sG FUT need 3sG

'Tomorrow... they will be the ones who need you.'

In FGC (though not in other French creoles, such as Martinican Creole), there is yet another deontic marker: pou ('for').

$$
\begin{aligned}
& \text { Pou mo bout } \\
& \text { for 1sG finish } \\
& \text { 'I have to finish.' }
\end{aligned}
$$

It is important to note that in FGC, deontic pou is always at the head of the phrase:

$$
\begin{aligned}
& \text { Pou mo alé koté doktèr } \\
& \text { for } 1 \mathrm{sG} \text { go by doctor } \\
& \text { 'I should go to the doctor.' }
\end{aligned}
$$

$$
\begin{aligned}
& \text { Pou to fé topa bati } \\
& \text { for 2sG make poss farm } \\
& \text { 'You should run your own farm.' }
\end{aligned}
$$

$$
\begin{aligned}
& \text { Pou li komprann } \\
& \text { for 3sG understand } \\
& \text { 'He should understand.' }
\end{aligned}
$$

In several French creoles, pou carries future or modal meaning that can be metonymically close to deontic meanings. This use is also attested in older FGC texts:

$$
\begin{aligned}
& \text { Zòt pou fè } \\
& \text { 2pL for do } \\
& \text { 'You should do it.' (Sournia 1976: 7) }
\end{aligned}
$$


However, this final example is different from modern use in its placement of pou. As indicated above, current FGC places pou before the subject pronoun:

$$
\begin{aligned}
& \text { Pou zòt fè } \\
& \text { for 2PL do } \\
& \text { 'You should do it.' }
\end{aligned}
$$

A concept such as reanalysis may explain the use of pou, "must", as a marker of deontic modality. As Lang and Neumann-Holzschuh (1999: 7) state, they use the term reanalysis "when a listener who has access to the structural order of the utterance gives the linear order a structural interpretation different from that implied by the speaker". ${ }^{2}$ We should add that reanalysis can lead to "rebracketing" (Haspelmath 1998: 330) as well as to "category relabelling" (Harris and Campbell 1995: 63; for detailed discussions with explicit reference to creole languages, cf. Neumann-Holzschuh and Schneider 2000; Kriegel 2003; Detges 2003; Neumann-Holzschuh 2003). A possible candidate for a reanalysis is the construction "in order to". To explain the emergence of this peculiarity of FGC, we may assume that the following reanalyses have occurred (cf. Pfänder 2003):

$$
\begin{aligned}
& \text { [I nésésèr pou mo] ale koté dokteur } \\
& \text { 3sG necessary for 1sG go side doctor } \\
& \text { 'It is necessary for me to go to the doctor.' }
\end{aligned}
$$

(148) I nésésèr [pou mo alé koté dokteur]
3sg necessary for $1 \mathrm{sg}$ go side doctor
'It is necessary that I go to the doctor.'

From the domain of necessity, we now move on to possibility. In FGC, pouvé (and allegro form vé) > fr. 'pouvoir' is used both for root ('be able

\footnotetext{
2"Von Reanalyse möchten wir [...] dann sprechen, wenn ein Hörer, dem der vom Sprecher intendierte "ordre structural" zugänglich ist, bei der Interpretation dem entsprechenden 'ordre linéaire' einen anderen 'ordre structural' unterstellt."
} 
to'), deontic ('be allowed to') and epistemic modality ('it might well be that...'). Thus, depending on the context,

$$
\begin{array}{lll}
\text { i pouvé alé } \\
\text { 3sG can } & \text { go }
\end{array}
$$

can mean 'he is able to walk', 'he is allowed to go' or 'maybe he can go'. Sometimes the context makes it clear that we are dealing with root modality meaning "be able to":

$\begin{array}{lllll}\text { Mè } & \text { nou } & \text { pa } & \text { pouvé } & \text { alé } \\ \text { but } & 1 \mathrm{PL} & \text { NEG } & \text { be-able } & \text { go } \\ \text { piske } & & \text { pa } & \text { gen } & \text { kannon } \\ \text { because } & & \text { NEG } & \text { have } & \text { boat }\end{array}$

'We were not able to go, because there weren't any boats.'

$\begin{array}{llllllll}\text { I } & \text { ka } & \text { bas, la } & \text { la } & \text { a } & \text { louvri pou louvri } \\ \text { 3SG } & \text { PROG } & \text { low } & \text { these } & \text { DEF } & \text { DEF } & \text { open for open } \\ \text { ou } & \text { janmb } & \text { pou pouvé } & \text { tire } & \text { mannyòk } & & \\ \text { POSS legs for be-able pull } & \text { manioc } & & \end{array}$

'It grows low; therefore, you have to move your legs out of the way to be able to pull up the manioc.'

If, on the other hand, the context displays markers of uncertainty, an epistemic reading is preferred by most speakers, as in the following example:

$$
\begin{aligned}
& \begin{array}{llllllll}
\text { Dimen } & \text { si } & \text { bondyé lé } & \text { pitèt } & \text { i } & \text { pouvé } & \text { alé } \\
\text { tomorrow } & \text { cond } & \text { God } & \text { will } & \text { maybe } & 3 \text { ss } & \text { can } & \text { go, }
\end{array} \\
& \mathrm{m}^{\prime} \text { pa save } \\
& \text { 1sG NEG know.' }
\end{aligned}
$$

Syntactic reorganisation (the position of the aspectual or temporal particle) enables semantic differentiation between epistemic and nonepistemic meaning. Therefore, in the following examples: 
$\begin{array}{lllll}\text { (153) I divèt té ka dronmi } & \\ \text { 3sG must PST PROG } & \text { sleep }\end{array}$

'Maybe he was sleeping.'

(154) I divèt ka travay

3sG must PROG work

'Maybe he is working.'

only an epistemic interpretation would be a natural choice in FGC (Peyraud 1983: 135).

\subsubsection{Imperative}

Imperative forms tend to be marked by $\varnothing$ in FGC (first example below), their negative form by $k a$ (second example):

(155) Fromen zòt bouch close poss mouth 'Close your mouth.'

(156) Pa ka ouvri zòt bouch NEG PROG open POSS mouth 'Do not open your mouth.'

As far as we know, this has not been reported for Martinican Creole.

Different morphological markers on imperatives and negated imperatives are quite common. Marking the negative imperative with the less assertive form is in this respect similar to languages like Spanish, in which the negated imperative is marked by the subjunctive mood:

(157) Dime

'Tell me.'

(158) No me digas

'Do not tell me.' 
Furthermore, FGC (like other creoles) makes good use of mitigated, so-called hortative imperatives:

$$
\begin{aligned}
& \text { Annou pati } \\
& \text { IMP leave } \\
& \text { 'Let's go.' }
\end{aligned}
$$

In Ewe, we find a similar structure:

$$
\begin{array}{lll}
\mathrm{Na} & \text { mí } & \text { dzo } \\
\text { give.2sG } & \text { 1PL } & \text { leave } \\
\text { 'Let's go.' (Ameka 1991: 52) }
\end{array}
$$

\subsection{Sentence Structure}

\subsubsection{Copula Constructions}

Very much like English, French has one copula, whereas FGC resembles Ewe, with three different copula constructions. ${ }^{3}$

First of all, in simple sentences with a predicate adjective, FGC uses a zero-copula strategy, just like Ewe, as illustrated in the following examples:

$$
\begin{array}{lll}
\text { FGC: } & \text { gran } \\
& \text { 3sG } & \text { tall } \\
& \text { 'He is tall.' } &
\end{array}
$$

Second, if the predicate involves a noun, the copula $s a$ is used in present tense contexts:

\footnotetext{
${ }^{3}$ Again, we can see that creolisation does not involve simplification nearly as often as early research suggested.
} 


$$
\begin{aligned}
& \text { I sa gran-grèk } \\
& \text { 3sG cop professor/researcher } \\
& \text { 'She is a professor at university.' }
\end{aligned}
$$

while the copula té is used in past-tense contexts:

$$
\begin{aligned}
& \text { Misyè té doktér avan } \\
& \text { He PST doctor before } \\
& \text { 'He was a doctor before.' }
\end{aligned}
$$

This again is similar to Ewe, in which different forms of the copulas lè and nò are used in similar present- (lè) and past-tense (nò) contexts.

Third, there is a separate copula for constructions that indicate the particular location of a person or an entity, as illustrated here:

$$
\begin{aligned}
& \text { I fika Kayèn } \\
& \text { 3sG coP Cayenne } \\
& \text { 'He is living in Cayenne.' }
\end{aligned}
$$

This type of spatial copula also exists in Portuguese. While all other copula forms, including sa and té, come from French, the locative copula fika is transferred from Portuguese, in which it seems to have the same functions as in FGC:

(166) Porto Allegre fica no sul do Brasil.

'Porto Allegre is located in the South of Brazil.'

(167) O professor Pereira fica mais dois anos na Universidade de São Paulo. 'Professor Pereria will stay at the University of São Paulo for two more years.'

(168) Hoje Anderson fica em casa.

'Anderson is staying home today.'

(169) A Juliane vai ficar dois meses em Berlim para estudar alemão 'Juliane will stay in Berlin for two months to learn German.' 
However, there is one function that has not been transferred to FGC:

$$
\begin{aligned}
& \text { Ele ficou surpreso.; } \\
& \text { 'He was surprised.' }
\end{aligned}
$$

We thus analyse the use of FGC fika as a slight refunctionalisation (reduction of functional range) of a Portuguese morpheme-a reduction that possibly took place due to Ewe influence.

\subsubsection{Negation}

In FGC, the negation marker is $p a$, 'not'. The double negative construction from French has not been transferred to FGC. Another important divergence between FGC and French can be found in the positioning of the negation marker $p a$. Negation is expressed by the particle $p a$, which precedes all tense-aspect-mood markers but follows the subject:

$$
\begin{aligned}
& \text { Pa gadé déyè } \\
& \text { NEG look back } \\
& \text { 'Do not look back!' }
\end{aligned}
$$

$\begin{array}{llll}\text { I } & \text { pa } & \text { gen frè } \\ \text { 3SG } & \text { NEG } & \text { have brother }\end{array}$

'He has no brother.' (Holder 1988: 6)

$\begin{array}{lllll}\mathrm{Si} & \text { to } & \text { pa } & \mathrm{ka} & \text { fè } \\ \text { COND } & \text { 2sG } & \text { NEG } & \text { PROG } & \text { make }\end{array}$

'if you don't do it.' (CIEL_FR_GF_RADIO)

(174)

$$
\begin{aligned}
& \text { Mo pa savé } \\
& \text { 1sG NEG know } \\
& \text { 'I don't know.' (CIEL_FR_GF_RADIO) }
\end{aligned}
$$

Nou pyès pa wè.

$1 \mathrm{PL}$ feet NEG see

'We don't see.' (CIEL_FR_GF_RADIO) 
(176) To pa aksepté hein to ka toléré.

2sG NEG accept right 2sG PROG tolerate

'You don't accept (it), no; you tolerate it.' (CIEL_FR_GF_RADIO)

(177) Sa yé pa ka wè pa ka fè ou mal DEM eye NEG IPFV SEE NEG IPFV make 2SG bad 'What the eye does not see, the heart does not grieve over. [What they don't see, doesn't hurt them]' (CIEL_FR_GF_RADIO)

(178) To pé pa fè sa

2sG can NEG make DEM

'You can't do that.' (CIEL_FR_GF_RADIO)

Unlike in French or English, all tense and aspect markers in FGC are placed between the negation marker and the main verb, as illustrated in examples below:

(179) Mo pa gadé déyè I NEG look back

'I do not look back.'

(180) Mo pa ka gadé déyè I NEG PROG look back 'I am not looking back.'

(181) Mo pa té gadé déyè I NEG PST look back 'I had not looked back.'

(182) Mo pa té ka gadé déyè I NEG PST PROG look back 'I was not looking back.' 
In most Gbe languages, the negation marker is combined with tense and aspect markers, which are also placed in between the negation marker and the main verb. Thus, at first glance, negation in simple sentences may appear to be a contact-induced innovation in FGC. However, if we take informal spoken French into consideration, the particle pas also mostly occurs preverbally due to periphrastic constructions:

FRENCH

Je
I

(ne) parle pas.
NEG speak NEG

$$
\begin{array}{lllll}
\text { Je } & \text { (ne) } & \text { vais } & \text { pas } & \text { parler } \\
\text { I } & \text { NEG } & \text { go } & \text { NEG } & \text { speak }
\end{array}
$$

FGC

$\begin{array}{llll}\text { Mo } & \text { pa } & \text { ka } & \text { palé } \\ \text { 1SG } & \text { NEG } & \text { PROG } & \text { speak }\end{array}$

Mo pa ké palé 1SG NEG PROG speak

What is nevertheless truly innovative is the possibility for tense and aspect markers to appear between the negation marker and the predicate in FGC.

Negative indefinite pronouns occur with the negation particle:

$$
\begin{aligned}
& \text { Mo pa wè pesòn } \\
& \text { 1sG NEG see nobody } \\
& \text { 'I did not see anybody.' }
\end{aligned}
$$

In the respective Standard French phrase Il ne parle pas, we observe that the etymologic NEG ne precedes the full verb, and the lexeme 'step' pas is lexicalised as the right negation bracket. Again, the oral input shows otherwise: the NEG ne/n/is frequently omitted, and in the cases in which it is realised, it is far less salient, meaning that $/ \mathrm{n} /$ is more difficult to identify in the sound chain than pas/pa/. Apart from the phonetic argument, there is also a syntactical explanation. In French, pas is placed after the inflected verb. If there is an auxiliary plus a full verb, pas 
appears after the finite auxiliary and before the non-finite full verb in its form as an infinitive or participle: Il n'a pas parlé or Il ne va pas parler. This means that in terms of perception, pas must have been audible before the verb in the input of early Cayenne society.

Word-order transfer from Ewe can be found to be successful in those cases for which the word order in question exists as a pragmatically heavily constrained structure in spoken French. A postposed intensifier, as in He is crazy, like, completely, for example, enables transfer from Ewe, where intensifiers occur in postposed position. Although the underlying structure in French involves reconstruction and is thus different from the underlying structure in Ewe, it can be perceived as a suitable target structure. Surface resemblance to Ewe wins out against frequency. Even if the French target structure is pragmatically marked and used infrequently, perceived similarity to an Ewe structure encourages word-order transfer. In other words, the idea is that speakers intend to use French word-order patterns but involuntarily gravitate towards those patterns that are similar to Ewe structures, even if they are infrequent and pragmatically constrained.

\subsubsection{Predicate Doubling}

Many structures of FGC have a repeated element that can work as a focus strategy and an intensifier:

$$
\begin{array}{lllll}
\text { A } & \text { pati } & \text { Georges } & \text { ka pati } \\
\text { DEM } & \text { leave } & \text { Georges } & \text { PROG left }
\end{array}
$$

'Georges left as if he were running for his life.'

(188) A chanté yé té ka chanté DEM sing 3PL PST PROG sing

'They were singing out loud.' [literally: 'It is singing; they were singing.']

While there is a very productive process of verb doubling embedded in a presentative or cleft construction with the particle $a$, 'this is' (from an Arawak etymon $a$, 'this/this is'; see Pfänder 2000a), the underlying 
origin is quite likely to be Ewe, in which more than $8 \%$ of words occur in a reduplicated form (Ameka 1999: 78). Repeated words in focus strategies are common:

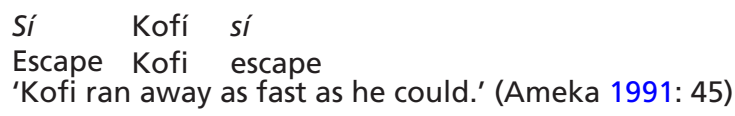

A common superlative construction in FGC involves repetition of the relevant noun phrase and a clause-final fet, apparently derived from fait, the past participle of the French verb faire, 'to make'. Note that the final consonant of fait was pronounced in many patois and regional varieties of French, so fet does not necessarily trace its origin from the feminine form.

$$
\begin{aligned}
& \text { To pè pasé pè fèt } \\
& \text { 2sG fear more fear made } \\
& \text { 'We [one] had never been so scared.' }
\end{aligned}
$$

$$
\begin{aligned}
& \text { Madanm troumantan pasé troumantan fèt } \\
& \text { Woman troublemaker more troublemaker made. } \\
& \text { 'She is the biggest troublemaker (I have ever met).' }
\end{aligned}
$$

The superlative structure is not from French, however. Ewe uses a similar repeated form for superlatives, in which "the two NPs are linked by the possessive connective $f^{\prime \prime \prime}$ :

$$
\begin{aligned}
& \begin{array}{l}
\text { Wó-be-na dé wó-fé } \quad \text { xo-wó me } \\
\text { 3PL-hide-HAB }
\end{array} \text { ALL PL-POSS room-pl containing.region.of at } \\
& \text { gogloefé fé gogloefé-wó } \\
& \text { deep.part pOss deep.part-PL } \\
& \text { 'They hide in their rooms in the most hidden part of all places.' } \\
& \text { (Ameka 1999: 89) }
\end{aligned}
$$

Repetition also occurs very frequently in narratives, as is apparent in many of the stories transcribed in Appendix: 


$$
\begin{aligned}
& \text { Nou pè nou pè nou pè } \\
& \text { 3PL fear 3PL fear } \\
& \text { 'We were very afraid.' }
\end{aligned}
$$

$$
\begin{aligned}
& \text { Mo ajounou mo ajounou } \\
& \text { 1sG kneel } 15 \mathrm{~s} \text { kneel } \\
& \text { 'I knelt down, I knelt down.' }
\end{aligned}
$$

The many instances of repetition might show transfer from Ewe, since they are not attested, at least not all of them, in French or another Romance language.

\subsubsection{Comparative Marking}

In French, there is variation between two comparative patterns. This is similar to English, where we find variation between comparative marking with more, comparative marking with -er, and suppletion: This event is more scandalous than the last one. /This event is cheaper than the last one. /This event is better than the last one. In French, variation can be found between comparative marking with more + positive adjective and suppletion. There is no morphologically marked comparative in French, and none of these syntactic strategies is attested to in the Gbe language family. Comparative marking in Gbe is illustrated in the example below:

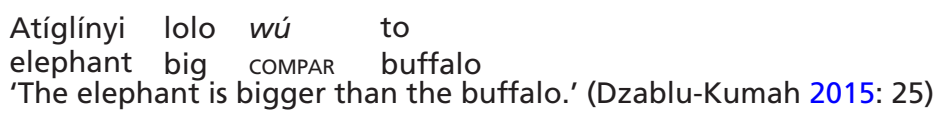

This structure in Ewe may have inspired the structure in FGC that is illustrated in the example below:

$$
\begin{aligned}
& \text { Zarb gran pasé kaz } \\
& \text { tree big surpass house } \\
& \text { 'The tree is bigger than the house.' }
\end{aligned}
$$

In the rainforest recordings, the verb pasé, 'surpass', is selected by default in order to mark the standard: 
(197)
Georges bel pasé Stéphane
George handsome surpass Steven
'George is more handsome than Steven.'

(198)

\begin{tabular}{|c|c|c|c|c|c|c|}
\hline $\begin{array}{l}\text { Mo } \\
1 \mathrm{sg}\end{array}$ & $\begin{array}{l}\text { ké } \\
\text { FUT }\end{array}$ & $\begin{array}{l}\mathrm{mo} \\
1 \mathrm{sg}\end{array}$ & $\begin{array}{l}\text { fè } \\
\text { make }\end{array}$ & $\begin{array}{l}\text { Oun } \\
\text { INDF }\end{array}$ & $\begin{array}{ll}\text { chanté } & \text { pou } \\
\text { sing } & \text { for }\end{array}$ & $\begin{array}{l}\text { to } \\
2 s G\end{array}$ \\
\hline $\begin{array}{l}\text { Pasé } \\
\text { Surpass }\end{array}$ & & $\begin{array}{l}\mathrm{mo} \\
1 \mathrm{sg}\end{array}$ & $\begin{array}{l}\text { jouré } \\
\text { insult }\end{array}$ & $\begin{array}{l}\text { to } \\
2 s G\end{array}$ & & \\
\hline
\end{tabular}

(199) Est-ce li gain langue, qui millò, pou ça, passé criole?

'Is there any language that is more beautiful than Creole?' (Parépou

1885: 12)

Comparative marking in FGC exhibits features of both Transfer Type 1 (functionalisation) and Transfer Type 3 (syntactic strategy). The lexeme surpass now functions as a grammatical marker of comparison within the complex construction $A$ adjective surpass $B$, which was transferred from Ewe.

\subsubsection{Comitative and Additive}

In French, the comitative avec ('with') and the additive et ('and') are different categories expressed through different markers, but in FGC, these categories are fused and both are expressed via comitative ké ('and, with' < French avec 'with'):

(200) Mo $\varnothing$ vini ké mo
I PFV come with poss.1sg family.

'I came with my family.' 
(201)

Papa ké manman Tipolo $\varnothing$ désidé voyé li an koloni vakans father сом mother little-Paul PFv decide send 3sG in campholiday 'Dad and mum decided to send their son Paul to a summer camp.' (Holder 1988: 3)

This extension of the functional range of ké ('with') might well be inspired by the Ewe form klpé which also combines comitative with additive (Dzablu-Kumah 2015: 14).

(202) Kofí kplé Ama (Ameka 1991: 59)

Kofí com Ama

'Kofi and Ama'

\subsubsection{Nominal Coreference}

Coreference between the subject and object can be expressed via object omission for body care and grooming verbs:

(203) l lavé

'S/he washes.' or 'S/he washes her/himself.'

Nominal coreference can also be established via the body (so ko , literally 'his/her body'):

(204) Kannon-a anni tounen anlè so kò boat-DEF just turn on poss body 'The boat just turned over.'

(205) Tipolo ka santi so-kò tou tris. Tipolo PROG feel himself totally sad 'Tipolo always felt sad.' (Holder 1988: 6) 
(206)

$\begin{array}{llllll}\text { Tipolo } & \text { sere } & \text { so } & \text { kò } & \text { tou } & \text { piti } \\ \text { Tipolo } & \text { make } & \text { Poss.3sG } & \text { body } & \text { very } & \text { small } \\ \text { annan } & t i & \text { kwen } & & & \\ \text { in } & \text { little } & \text { corner } & & & \end{array}$

'Tipolo is hiding away in a corner.' (Holder 1988: 6)

or via body parts (e.g. so tchò, literally 'his heart'):

(207)

$$
\begin{aligned}
& \text { Mo té di mo tchò } \\
& \text { I said to POss.1sg heart } \\
& \text { 'I said to myself' }
\end{aligned}
$$

$$
\begin{aligned}
& \text { A oun moman mo té di mo tchò. } \\
& \text { at INDF moment 1sG PST from POSs heart } \\
& \text { 'At some point, I will say to myself [lit. 'to my heart'] /l told myself.' } \\
& \text { (CIEL_FR_GF_RADIO) }
\end{aligned}
$$

$$
\begin{aligned}
& \text { Sa ka fè to chò mal. } \\
& \text { DEM PROG make POss.2sG heart sick } \\
& \text { 'This hurts you [lit. This is making your heart sick].' } \\
& \text { (CIEL_FR_GF_RADIO) }
\end{aligned}
$$

In FGC, these expressions are no longer lexical, and we tend to speak of incipient grammaticalisation. The fact that they are written as one or two words and translated by native speakers as 'myself', 'my body' or 'my heart' provides solid evidence for this conjecture; however, further research is clearly needed here. In Ewe, we have a self-based construction, as in English (cf. Dzablu-Kumah 2015: 143), so there is no functional transfer from Ewe here, but rather innovation or transfer from other contact languages.

Reciprocal relationships are expressed with the reciprocal pronoun kompagnen, 'each other' (originally 'friend', < French compagnon): 
(210) Wonm-yań tchoué yé kompannyen

Men-DEF kill 3PL RECP

'They killed each other.'

This syntactic strategy may be a transfer from the very similar Ewe strategy:

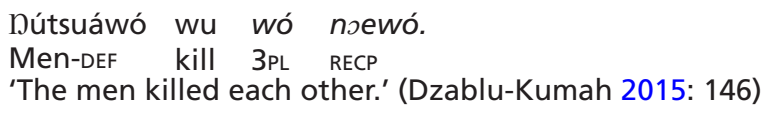

Dútsuáwó wu wó nəewó.

Men-def kill 3PL RECP

'The men killed each other.' (Dzablu-Kumah 2015: 146)

Again, we can speak of weak or incipient grammaticalisation of reciprocity here.

\subsubsection{Wh-Questions}

The interrogative phrase in FGC is fronted in content questions:

(212) kimoun to wè?
Who 2sG see
'Whom did you see?'

In French, each wh-question is introduced by a specific lexical item (where, who, what). FGC did not inherit those interrogative pronouns, although they should have been part of everyday conversation. Transfer (morphosyntactic strategy, and in this case, also syntactic transparency via analogy) thus trumps frequency. In FGC, innovative bipartite interrogative pronouns are used. They are based on a lexicalisation process that involves a noun, such as side, site, person or thing, combined with an unmarked interrogative pronoun, $k i$.

(213) ki-koté

which-side

'where'

(214) ki-moun

which-person

'who' 
(215) ki-bagay

which-thing

'what'

This seems to be due to transfer from Ewe, where we can find the same strategy that combines a noun with an interrogative pronoun.

(216) afí-ka

here-which

'where' (Pasch 1995: 80)

(217) ame-ka

person-which

'whose' (Ameka 1991: 176)

(218) nú-kà

thing-which

'what' (Pasch 1995: 79)

Nevertheless, in some cases, the interrogative pronoun $k i$ is omitted, and the noun itself is used as the interrogative pronoun.

(219) "Mé to, frè!" dit Atipa. "Côté to soti?" but 2sG brother say Atipa side 2sG go out '"There you are, brother," said Atipa. "Where did you come from?"' (Parépou 1885: 14)

(220) Koté sa timoun-yan k'alé?

where DEM child.INDF.PL go-PROG

'Where are all those children going?' (Holder 1988: 5)

(221) Koté zot ka alé... annan chan lougarou-a? where 2PL PROG go into field werewolf.DEF 'Where are you going? Into the "werewolf field"?' 
In these examples, koté is used as an interrogative pronoun meaning where. In our corpus, koté is also used to indicate a place where someone lives (koté docteur, 'at the doctor's; koté koumèr, 'at the neighbour's) and as a locative adverb (toutkoté = 'everywhere'). From a usage-based perspective, the fusion process still seems to be underway. One piece of evidence can be seen in the written depiction of these items as one or two words.

Thus far, we have discussed a syntactic strategy transfer for the interrogative pronouns; however, there is another syntactic strategy transfer to report, namely the emergence of a morphosyntactically realised question marker:

(222) Kisa l' fè a

what 3sg do Q

'What did he do?' (CIEL_FR_GF_RADIO)

The function (and form) is quite similar to what has been noted for Gbe languages, for example, Ewe and Fon:

Kofí dzó a?

Kofí leave Q

'Has Kofí left?' (Ameka 1991: 54)

(224) É KÁ
It NÁ sìxú kpé

'Could that be enough now?' (Fon, cf. Akoha 2010: 105)

Whether this is a clear case of functional transfer or whether the whole form-function unit is transferred here would be a worthy subject of later research. Even if the forms appear similar, they could also be functionalised allegro forms of the independently existing pragmatic markers, which have been discussed for the French language by Wiesmath (2003) and Ludwig and Pfänder (2003) and for Ewe by Lafage (1985) and Ameka (1991).

A third and again very clear case of transfer of the mophosyntactic strategy in the realm of question marking can be found in 
the construction (literally) that who/those who, often best translated by 'whoever', which we find in both FGC (225) and Ewe (226):

(225)

$\begin{array}{lll}\text { Sa } & k i & \text { douvan, rantré } \\ \text { DEM } & \text { REL in front, turn } \\ \text { 'Whoever is in front of me, turn around.' }\end{array}$

(226)

ame-si

person-who

'whoever' (Dzablu-Kumah 2015: 132)

\subsubsection{Relative Clauses}

In FGC, the relative clause is marked either by preposed relative pronoun $k i$, as in the following example

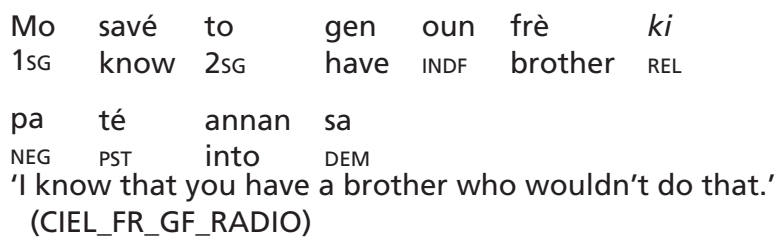

or by $k i$ and additionally a postposed right bracket $a$, as in this example:

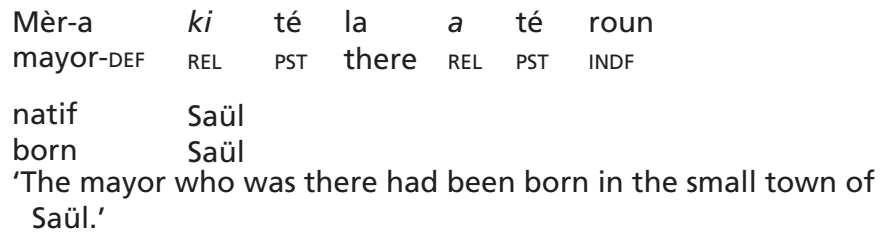


This use of $a$ as a right bracket of a relative clause might be analysed as the functionalisation or refunctionalisation of the pragmatic tendency found in many varieties of French (and used to emphasise the definite article le/la) and as restrictive relative clauses with a right bracket là (cf. Ludwig and Pfänder 2003). In some cases in French, là functions as a right bracket for a larger noun phrase or a relative clause. In many varieties of French on the African Continent (as well as in America and Europe), we find a right bracket of larger syntagmatic unit, often a relative clause, as in the following examples:

(229) lui qui vient là (Ploog 2000: 1423/217)

'(the guy) who came LA'

(230) (les) jeunes là qui venaient là (Martel and Beauchemin 1973: 22)

'the young people LA who came $L A$ '

(231) celle-là qu'a fait le canal-là (Stäbler 1995: 73)

'the one who built the canal $L A^{\prime}$

(232) le truc que tu m'as passé là (Ludwig 1996: 319)

'the thing you gave me $L A^{\prime}$

(233) les petites affaires rouges t'as mangées là (Canada, Wiesmath 2000) 'the little red things that you ate $L A$ '

It is important to note that while in French, these right-bracket constructions are only a tendency - a routine form of structuration from a pragmatic point of view-their creole equivalents are part of creole core grammar.

In order for this to happen, transfer from Ewe cannot be excluded. Ameka (1991: 267) reports strikingly similar uses of "information structure" as he has it, in Ewe: 
(234)

$$
\begin{array}{lllllll}
\text { ga } & \text { si } & \text { ne } & \text { do' } & \text { de'- } & \text { m la' } & \text { la' } \\
\text { money } & \text { REL } & 2 s G & \text { send to } & \text { 1sG } & \text { TP } \\
\text { 'the money you sent } & \text { me' (Ameka } & 1991: & 267 \text { ) }
\end{array}
$$

Lafage (1985: 399; 406-407) reports a postposed marker -là with falling intonation that has a function of "modalité de precision" (a "precision marker") and a final particle -lá with rising intonation (note the diacritic), which the author labels "particule finale de subordonnée" (a "final subordinating particle") (1985: 399).

\subsection{Results and Discussion}

In this chapter, we have analysed important features of FGC core grammar in the light of four transfer types: functionalisation, refunctionalisation, morphosyntactic strategy and (semantic) category. In the following sections, we examine each strategy, provide a list of all the features we identify as belonging to each type and discuss the implications of these findings for the dichotomy of innovation and inheritance in the emergence of FGC.

\subsubsection{Revisiting the Four Types of Transfer}

\subsubsection{Functionalisation}

During functionalisation, or functional transfer Type 1 (see Sect. 3.1.4), a lexeme acquires grammatical function. While the form is clearly inherited, the function is innovative (from lexical to grammatical). In FGC, functionalisation is maybe best illustrated using the verb surpass as a comparative marker, as in Georges gran pasé Steven, literally: Georges tall surpass Steven, 'Georges is taller than Steven'. Another functionalisation process can be found in the usage of misye and madanm, which serve as personal pronouns (3SG) in FGC. We find a similar process in Brazilian Portuguese, where the lexeme a gente ('the people') is used as the personal pronoun we. A further example of functionalisation has been 
described in the fusion of the personal pronoun mo (mon 'my') with the lexeme pa (part 'part'). When it comes to verbal phrases, we again find instances of functionalisation. The emergence of a reflexive pronoun from nouns referring to the body or body parts, for example, is a very common functionalisation process that can be considered an areal characteristic of West African languages even if Ewe is an exception that uses a postposed word meaning 'oneself'. The French reflexive pronoun is preposed so speakers of West African languages in French Guiana may have grammaticalised the expression 'son corps' ('his/her body') to fill the gap where they expected to find the pronoun. In FGC, the combination of the personal pronoun so and the lexeme kò has taken on the grammatical function of a reflexive pronoun in phrases such as $i$ ka tchoué sokò ('he killed himself'). Other body parts can be used in the same way, as we can see in so tchò in FGC.

Our analysis suggests that functional transfer Type 1 is crucial for an in-depth understanding of the creation of a new language such as FGC. When compared with the structure of standard French, these structures appear highly innovative. From a more general perspective, however, these structures are not necessarily surprising as they follow well-established pathways of grammaticalisation (cf. Heine and Kuteva 2002). Siegel (2012), though, argues that we should not consider them as such because grammaticalisation processes take a long time. If at all, grammaticalisation processes should then bridge the gap between two languages - that is, they may begin in one language and continue in the contact language (cf. Ludwig and Pfänder 2003). This issue needs to be addressed in further research.

\subsubsection{Refunctionalisation}

Refunctionalisation has been shown to be a critical strategy in contactinduced dialect change, such as in Andean Spanish and in varieties of English in the Pacific. In FGC, we have found refunctionalisation from French to be less productive than functionalisation, which is in line with Siegel's (2015) findings. Refunctionalisation is not as productive in creolisation as in contact-induced dialect change (e.g. in Andean Spanish) mostly because input from French is less complete and less 
intense. In the case of incomplete input, the lexicon is more readily accessible than are possible (grammatical) candidates for refunctionalisation. Our analyses in Sects. 3.2, 3.3 and 3.4 and of the FGC corpus in the Appendix have found the following cases of refunctionalisation in FGC:

The third-person singular form 'va' of the verb 'to go' has become generalised, without undergoing significant semantic change, as the future marker 'wa'.

$$
\begin{aligned}
& \text { Nous wa mangé tout lé dé." } \\
& \text { 1PL FUT eat all DEF.PL two } \\
& \text { 'The two of us are going to eat (together).' } \\
& \text { (Parépou 1885: 44) }
\end{aligned}
$$

Another marker in FGC is a generalised form of a French verb. Té, derived from various parts of 'être' ('to be'), has acquired many different functions (see Sect. 3.3.6).

$$
\begin{array}{llll}
\text { I té gen dé ròt kannon } \\
\text { 3sG PST have INDF.PL other boats } \\
\text { 'since there were other boats' }
\end{array}
$$

$$
\begin{aligned}
& \text { Mo té fè mo granlajan } \\
& \text { 1SG PST make poss big-money } \\
& \text { 'I made a lot of money.' }
\end{aligned}
$$

A similar case arose with the modal marker divèt, derived from forms of the verb 'devoir', which has become generalised and is used as a marker of epistemic modality in FGC.

$$
\begin{aligned}
& \text { I divèt té ka dronmi } \\
& \text { 3sG must PST PROG sleep } \\
& \text { "Maybe he was sleeping." (Peyraud 1983: 135) }
\end{aligned}
$$

The interrogative and relative pronoun 'qui' is now very productive and has been refunctionalised across a wide range, from a generalised relative pronoun (qui/que/dont) to acomplementiser ('I think that you ...') as 
well as contributing to new lexicalisations, such as kimoun, kitan and kikoté.

Instead of using the highly frequent inherited interrogative pronouns 'who', 'where', 'when' and 'what', FGC makes use of a refunctionalised marker $k i$, fused with nouns like 'people', 'side', 'time' and 'thing'.

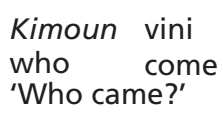

In the construction a pou ('you must'), pou expresses deontic modality instead of finality:

$\begin{array}{llllllll}\text { (240) I } & \text { di: } & \text { "Manman a } & \text { pou mo mennen ou } \\ \text { 3sG } & \text { say } & \text { mum } & \text { DEM for } & \text { 1sG take } & \text { 2sG } \\ \text { koté } & \text { oun } & \text { espisyalis!" } & & & & \\ \text { side } & \text { INDF } & \text { specialist } & & & & \end{array}$

'She [my daughter] said, "Mum, we have to take you to a specialist!"'

In FGC, the functions of commitative ('with his wife'), instrumental ('with a spoon') and additive ('a man and a woman') are all expressed with ké ('with'), thus we observe a refunctionalisation in the form of an expansion of functions.

$$
\begin{aligned}
& \text { (241) Wonm ké famn vini } \\
& \text { Man com women come } \\
& \text { 'a man and a woman came' }
\end{aligned}
$$

There exists at least one case of reduction of functional range of the definite article oun ('a') which is omitted in general expressions like:

$$
\begin{aligned}
& \text { (242) fè to wonm } \\
& \text { make 2sG man } \\
& \text { 'You have to be a real man.' }
\end{aligned}
$$

The right bracket '-là of the French demonstrative pronoun 'ce N-lă' has been refunctionalised as the FGC postponed singular definite article $-a$. 
Since the definite article is less obligatory than in French, $-a$ is closer to a demonstrative.

$$
\begin{aligned}
& \text { kaz-a } \\
& \text { house-def } \\
& \text { 'the house' }
\end{aligned}
$$

Note that two other sources of $-a$ are possible, including a Type 1 functional transfer; the locative adverb là is a lexeme that already in French can have the pragmatic function of identifying both deictically ('the person there') and/or anaphorically ('the person mentioned earlier'). The second source is a direct transfer (borrowing) since the Ewe morpheme $-a$ has the same form and function. Ewe has both $-l a$ and $-a$ as allomorphs, but seems to prefer $-a$. Although direct transfer seems the most obvious explanation, it does not account for why none of the other 30 or so tranfers of Type 1 to 4 are directly borrowed from Ewe (though this has been attested for other contact languages, cf. Pfänder 2009). It should be remembered that these various pathways are not competing but convergent. Speakers may subconsciously use different pathways to arrive at the same result.

The French deictic expression 'eux-là' ('those') has acquired a new function as a plural marker $(\mathrm{ya} / \mathrm{n})$ instead of pragmatic precision/deixis.

$$
\begin{array}{ll}
\text { tifi-ya; } & \text { timoun-yan } \\
\text { girls-DEF.PL } & \text { boys-DEF.PL } \\
\text { the girls } & \text { the boys }
\end{array}
$$

Note that an alternate pathway resulting from a morphosyntactic strategy transfer and functionalisation Type 1 is possible. $Y a$ was first attested as yé $l a$, and Ewe has a postposed personal pronoun 3PL that follows the definite article. However, the word order in Ewe is different and this transfer should have yielded la yé instead of yé la. Ewe speakers would have found eux là to be salient because it was in the right place for an Ewe plural marker. It would also have been frequent in the spoken French given as orders to slaves. Again, as with the singular - $a$, converging pathways increased the chance that a particular feature would be transferred from Ewe to FGC. 
Finally, FGC has right-bracket marking relative clauses that can be analysed as a refunctionalisation of the definite article:

(245) Boug ki vini a
Man REL come REL
'the man who came'

\subsubsection{Syntactic Strategy Transfer}

Our study has found many cases of syntactic strategy transfer, the most salient of which are detailed here.

While there is no syntactic strategy in French that includes a sentence-final interrogative marker, Ewe has a grammaticalised question marker:

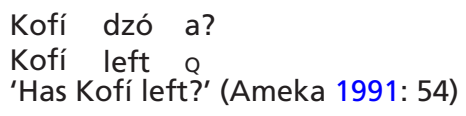

We find the same marker with the same function in FGC:

$$
\begin{aligned}
& \text { Georges pati a? } \\
& \text { Georges left } Q \\
& \text { 'Has Georges left?' }
\end{aligned}
$$

Instead of making use of the highly frequent French interrogative pronouns qui, 'who'; où, 'where'; que, 'what'; and quand, 'when', FGC developed a completely new paradigm of wh-pronouns (kimoun, kikoté, kisa, kitan; literally which people, which side, etc.) that imitate the syntactic strategy of Ewe (afi-ka).

In French, the intensifier is marked preverbally with the adverb très, 'very'. In FGC, however, the intensifier uses the postposed lexeme beaucoup, 'much':

(248) Zarb-a gran bokou

Tree-DEF big much

'The tree is very big.' 
Again, this seems to be a syntactic strategy transfer from Ewe:

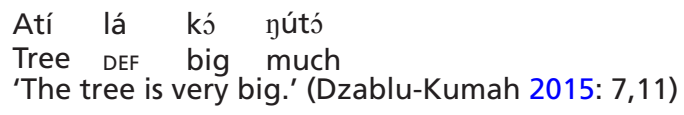

Ewe makes no use of a preposition if things are contextually clear:

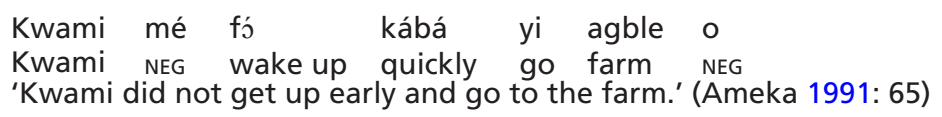

We find the same strategy in FGC:

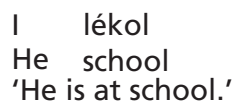

Another, often-disputed topic is that of serial verbs. Space does not permit a detailed study, but it is noteworthy that both Ewe and FGC display syntactic strategies that have been classified as serial verb constructions:

$$
\begin{aligned}
& \text { É fó } \quad \text { do go } \\
& \text { 3sG arise } \\
& \text { 'He go out out.' (Ameka 1991: 58) }
\end{aligned}
$$

(253) I soti alé

I alé désann

'She left.'

One type of serial verb construction is classified as a focus strategy. As we do not find this kind of syntactic strategy in French, we propose classifying this strategy as a transfer from Ewe:

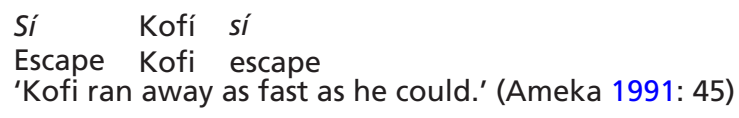


(255) A pati Georges ka pati it.is leave Georges PROG leave 'Georges left as if he were running for his life.'

As the example above suggests, there is some use of serial verbs by the Guianese, especially for verbs of movement:

(256) Georges ké Marie kouri alé Georges com Mary run go 'Georges and Mary went away quickly.'

Unmarked verbs have a present reading for statives (cf. first example below) but may have a past reading for dynamic verbs (second example below):

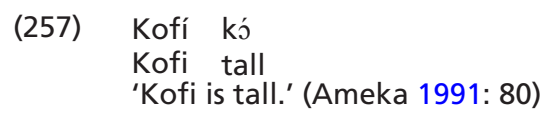

'Kofi is tall.' (Ameka 1991: 80)

(258) Kofí vă

Kofi come

'Kofi came.' (Dzablu-Kumah 2015)

We find the exact same distinction in FGC, as discussed in Sect. 3.3:

(259) $\begin{aligned} & \text { Georges gran } \\ & \text { Georges big } \\ & \text { 'Georges is big.' }\end{aligned}$

(260) Georges vini Georges come

'Georges came.'

A very clear example of syntactic transfer from Ewe is the comparative construction, which in FGC uses 'pasé' ('to surpass') after the adjective: 
(261) he gran pasé ròt 'He is taller than the other (person).'

Ewe does exactly the same, using the verb 'wú' ('to surpass') after the adjective:

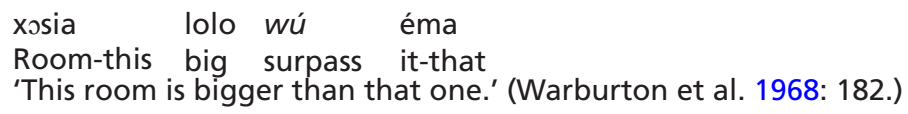

In FGC, word order is the same, regardless of whether the object is pronominalised or not (as in English):

$$
\begin{aligned}
& \text { Yé ka vandé kaz-a } \\
& \text { 3pL PROG sell house-DEF } \\
& \text { 'They sell the house.' }
\end{aligned}
$$

(264) Yé ka vandé $l^{\prime}$

3PL PROG sell 3sG

'They are selling it.'

(265) Ils vendent la maison.

'They are selling the house.'

(266) Ils la vendent

'They are selling it.'

Here, FGC clearly is in line with Ewe, but contrasts with French; in French, the object is normally postverbal, but the pronoun is pre-verbal.

\subsubsection{Category Transfer}

Comparison of FGC with French reveals at least two semantically defined categories expressed in different ways. Whereas both FGC 
and French make use of copulas, in French, there is only one copula expressed with conjugated forms of être ('to be'), but in FGC, there are three types of copulas: zero, sa and fika. Fika is used as a locative copula (I fika Cayenne 'he is in Cayenne'), sa is used as an existential copula ( $I$ sa dantis 'he is a dentist') and zero is used for all other purposes (I gran 'he is tall'). Maybe the most striking difference between French and FGC is the overwhelming tendency in FGC to express aspect and only rarely tense, whereas French strongly emphasises tense. These divergences between FGC and French can be classified as (semantic) category transfers from Gbe languages. Ewe works the same way as FGC for copulas (Dzablu-Kumah 2015: 46) and aspect (2015: 51).

\subsubsection{A Usage-Based Perspective on Creole Grammar}

Our analysis of some thirty features of FGC grammar is inspired by usage-based linguistics, a theoretical framework that aims to explain language variation and change from the perspective of the listener and her or his individual experience of language. We therefore followed two basic premises in our research:

(a) Perception outweighs formal classification. A participant might believe that a particular segment or element of a second language is relevant even if a grammarian would say otherwise. Listeners might perceive French lexical compositions such as 'est-ce' /, vous autres' or 'de l'eau' as a single word (es /zòt / dlo).

(b) Ecological conditions are key to language perception. This premise means that if the slaves were able to agree on one African lingua franca like Ewe, there was no need for them to create a new language within their community. The relative numerical parity of slaves and slaveholders and the presence in effect of only two languages in the colony (as presented in Chap. 2) led us to expect that the variety of French that the slaves used to communicate with slaveholders would have been more Ewe-like than other French-lexicon creoles.

Drawing from these considerations, we report the following concerning FGC grammar: 
- Good evidence for one or several types of transfer from Gbe languages for all 30 features of FGC analysed.

- Confirmation of Siegel's claim that the four types of linguistic transfer are sufficient to model all of the investigated features. Three of the four types of transfer were especially successful, namely the transfer of morphosyntactic strategies and the two types of functional transfer.

- FGC displays many instances of frequency effects, salience-induced changes, reanalyses and entrenchment. The small amount of input instead leads to the hypothesis that salience outplays frequency in FGC (' $l e$ ' as an article is highly frequent in French, but the FGC marker '-la' derives from the more salient demonstrative 'ce mec-là'; 'ou' is frequent, but the question marker is 'kikoté').

- Experience is the decisive factor in the creation of a new language. Listeners simply analyse what they hear in an L2, but each person perceives language potentially differently because there is no written input or formal teaching by native speakers.

Interaction studies combined with cognitive studies may in future provide important insights to help identify which kinds of features were frequent and salient in the colonial language contact situation and which combination of features is cognitively plausible and follows wellknown grammaticalisation paths. To sum up, we could thus formulate three basic constraints to transfer.

1. Phonetic salience. In the French example ce type-là, 'that guy' (lit. the guy there), the first part, ce, is phonetically much less salient than the final part, là, and does thus not qualify for being transferred.

2. Syntactic slots. In most West African languages, the article is postposed. This makes the transfer of the postposed item, là, more likely than the transfer of the preposed item, $c e$.

3. A semantic constraint. Interestingly, most of the functionalisation and refunctionalisation processes follow well-known paths of grammaticalisation and thus generally involve metonymic changes.

All three constraints can be easily explained from a usage-based perspective. We therefore close this chapter by reiterating a strong plea for a usage-based approach to language contact and creolisation. 
In language acquisition, variation and change, a clash of two of the main principles, namely frequency and salience, is possible, especially within a usage-based paradigm. The concept of frequency assumes that the user will acquire or transfer the most commonly heard of competing variants. On the other hand, the most salient version might win out even if it is not heard as much as other versions. In FGC, salience seems to dominate, perhaps due to the extreme social context of creolisation that restricts the learner's access to the language. Examples in which salience predominates include the demonstrative marker la instead of highly frequent $l e$ and the interrogative pronoun $k i(<, q u i)$ instead of $k e\left(<, q u e^{i}\right)$.

By assuming that speakers had no choice but to work with the heterogeneous language situation in which they found themselves, our aim in this study was to demonstrate how fruitful it is to combine both archive work and corpus analysis (Ennis and Pfänder 2010, 2013). Among other things, the archive work in Chap. 2 revealed that the early decades of settlement in French Guiana showed no record of a significant number of Bantu speakers. This finding fits perfectly with the linguistic observations in this chapter, namely that the divergences between FGC and MAC can be linked to Bantu influence on creole formation in Martinique (where a Bantu population was attested) (Crane et al. 2011). Among these divergences:

- In FGC, possessive pronouns are preposed, as in many (but not all) Gbe languages, but postposed in MAC, as in Bantu languages.

- FGC and Gbe languages like Ewe share the feature of an overt question marker; this is not the case for MAC, and not as far as we have found for Bantu languages.

- Aspect is important for all French-based creoles, but more important than tense in both FGC and Ewe; this clear preponderance of aspect over tense has not been reported for MAC or for Bantu languages.

These initial findings suggest that further research into comparative Bantu influence on creoles is needed.

This study has also made a number of findings about inheritance and innovation. Regarding inheritance, it might be conducive to regard a rhizome structure as the basic assumption instead of a one-track root. 
In a complex multilingual setting such as that of early French Guiana, we might want to use the metaphor of multiple birth (cf. Aitchison 1995) and might show continuity in every feature in more than one language. There are further traditional assumptions of language that need to be challenged: a language is not a comprehensive dictionary that can simply be transferred, and its grammar is not an integral system. After all, we can easily conceive of inheritance as being based on people's daily life experiences, on the constructions and routines they hear (and want to hear). In this sense, we wish to stress the materiality of inheritance (as in the social routine of greeting gestures) as well as people's drive to seek patterns and to access and acquire routines and structures. This directly relates to questions of power within the specific sociohistorical context, namely a slave-based plantation society in which the slaves' relation to language is framed by two distinct hierarchies as they communicate with those in power and with fellow slaves.

Regarding innovation, the findings of both the history and the linguistics chapter encourage us to think that creole genesis should not be misunderstood as a process that begins from square one. The emerging language might well represent a gestalt-like whole and a genuinely new entity, but if we look closely at each grammatical feature, we see that there is much continuity in material inherited from parent languages.

Siegel writes that "the development of pidgins and creoles shows language to be a multifaceted, ever-changing system of communication that is highly adaptive to the requirements of its use and to the environment it is used in" (Siegel 2008: 279). This study of FGC encourages us to conceptualise language creation not as an innovation from scratch, but rather as a combination of inherited elements from various languages that are perceived and identified by the speakers as material for creating a new language.

\section{References}

Aitchison, Jean. 1995. Tadpoles, Cuckoos, and Multiple Births, Language Contact and Models of Change. In Linguistic Change Under Contact Conditions, ed. Jacek Fisiak, 1-13. Mouton de Gruyter: Berlin and New York. 
Akoha, Albert Bienvenu. 2010. Syntaxe et lexicologie du fon-gbe, Bénin. Paris: L'Harmattan.

Ambridge, Ben, Evan Kidd, Caroline F. Rowland, and Anna L. Theakston. 2015. The Ubiquity of Frequency Effects in First Language Acquisition. Journal of Child Language 42 (2): 239-273.

Ameka, Felix. 1991. Ewe: Its Grammatical Constructions and Illocutionary Devices. München: Lincom Europa.

Ameka, Felix. 1999. The Typology and Semantics of Complex Nominal Duplication in Ewe. Anthropological Linguistics 41 (1): 75-106.

Andersen, Roger. 1983. Transfer to Somewhere. In Language Transfer in Language Learning, ed. S. Gass and L. Selinker, 177-201. Newbury: Rowley, MA.

Andersen, Henning. 1989. Understanding Linguistic Innovations. In Language Change: Contributions to the Study of Its Causes, ed. Leiv E. Breivik and Ernst H. Jahr, 5-28. Berlin: Mouton de Gruyter.

Andersen, Roger W. 1990. Papiamentu Tense-Aspect, with Special Attention to Discourse. In Pidgin and Creole Tense-Mood-Aspect Systems, ed. John V. Singler, 59-96. Amsterdam and Philadelphia: John Benjamins.

Baptista, Marlyse, Susan A. Gelman, and Erica Beck. 2014. Testing the Role of Convergence in Language Acquisition, with Implications for Creole Genesis. International Journal of Bilingualism 20 (3): 269-296.

Behrens, Heike. 2009. Usage-Based and Emergentist Approaches to Language Acquisition. Linguistics 47: 383-411.

Bickerton, Derek. 1981. Roots of Language. Ann Arbor: Karoma.

Blumenthal-Dramé, Alice. 2012. Entrenchment in Usage-Based Theories: What Corpus Data Do and Do Not Reveal About the Mind. Berlin and New York: De Gruyter.

Bolé-Richard, Rémi. 1983. Systématique phonologique et grammaticale d'un parlé ewe: le gen-mina du Sud-Togo et Sud-Bénin. Paris: L'Harmattan.

Boutin, Béatrice Akissi and Françoise Gadet. 2012. Comment ce que montrent les français d'Afrique s'inscrit / ne s'inscrit pas dans les dynamiques des français dans une perspective panfrancophone. Le Francais en Afrique 27: 19-34.

Bruyn, Adrienne. 1996. On Identifying Instances of Grammaticalization in Creole Languages. In Changing Meanings, Changing functions: Papers Related to Grammaticalization in Contact Languages, ed. Philip Baker and Anand Syea, 29-46. London: University of Westminster Press.

Bruyn, Adrienne. 2011. Grammaticalization in Creoles. Ordinary and NotSo-Ordinary Cases. In Language Change in Contact Languages: Grammatical and Prosodic Considerations, ed. Clements Clancy and Gooden Shelome, 53-78, Amsterdam: John Benjamins. 
Bybee, Joan L. 2006. From Usage to Grammar: The Mind's Response to Repetition. Language 82 (4): 711-733.

Bybee, Joan L., and Sandra Thompson. 1997. Three Frequency Effects in Syntax. In Proceedings of the Twenty-Third Annual Meeting of the Berkeley Linguistics Society: General Session and Parasession on Pragmatics and Grammatical Structure, 378-388. California: Berkeley.

Cacciari, Cristina (ed.). 1995. Similarity in Language, Thought and Perception. Brussels: Brepols.

Cheshire, Jenny. 2006. Sex and Gender in Variationist Research. In The Handbook of Language Variation and Change, ed. Jack K. Chambers, Peter Trudgill, and Natalie Schilling-Estes. Malden, MA and Oxford: Blackwell.

Contout, Auxence. 1973. Le patois guyanais. Cayenne: Laporte.

Corne, Chris. 1971. Le patois créole français de la Guyane (St-Laurent-duMaroni): esquisse de grammaire. Te Reo: Journal of the Linguistic Society of New Zealand 14: 81-103.

Cox, Christopher. 2013. The Resilient Word: Linguistic Preservation and Innovation Among Old Colony Mennonites in Latin America. Journal of Mennonite Studies 31: 51-74.

Crane, Thera M., Larry M. Hyman, and Simon N. Tukumu. 2011. A Grammar of Nzadi: A Bantu Langugage of Democratic Republic of Congo. Berkeley: University of California Press.

Cutler, Anne, Murty Lalita, and Otake Takashi. 2003. Rhythmic Similarity Effect in Non-native Listening. In Proceedings of the Fifteenth International Congress of Phonetic Sciences, 329-332. Barcelona.

Damoiseau, Robert. 1979. Etude syntaxique du créole d'un locuteur martiniquais unilingue. Paris: U.E.R. de linguistique générale et appliquée.

Damoiseau, Robert. 1984. Éléments de grammaire du créole martiniquais. Fortde-France: Hattier-Antilles.

Detges, Ulrich. 2003. La notion de réanalyse et son application à la description des langues créoles. In Grammaticalisation et réanalyse. Approche de la variation créole et française, ed. Sybille Kriegel, 49-67. Paris: CNRS Editions.

Dzablu-Kumah, Simon W. 2015. Basic Ewe for Foreign Students. Köln: Köppe.

Eckert, Penelope. 2008. Variation and the Indexical Field. Journal of Sociolinguistics 12: 453-476.

Eklou, Akpaka A. 1987. Satzstruktur des Deutschen und des Ewe: eine kontrastive Untersuchung im Rahmen der Dependenz-Verbvalenz-Grammatik. Africana Saraviensa linguistics, 14. Saarbrücken: Institut für Phonetik, Universität des Saarlandes. 
Ellis, Nick C. 2012. What Can We Count in Language, and What Counts in Language Acquisition, Cognition, and Use? In Frequency Effects in Cognitive Linguistics Vol. 1: Statistical Effects in Learnability, Processing and Change, ed. Stefan Th Gries and Dagmar S. Divjak, 7-34. Berlin and Boston: De Gruyter.

Enfield, Nicholas J. 2005. Areal Linguistics and Mainland Southeast Asia. Annual Review of Anthropology 34: 181-206.

Ennis, Juan Antonio. 2008. Decir la lengua. Debates ideológico-lingüisticos en Argentina desde 1837. Frankfurt a. M.: Peter Lang.

Ennis, Juan, and Stefan Pfänder. 2010. Zur -fragwürdigen- Legitimation des Laboratoriums Kreol(istik). In Tout-monde. Interkulturalität, Hybridisierung, Kreolisierung. Kommunikations- und gesellschaftstheoretische Modelle zwischen "alten" und "neuen" Räumen, ed. Ralph Ludwig and Dorothee Röseberg, 257-282. Frankfurt a. M.: Lang.

Ennis, Juan, and Stefan Pfänder. 2013. Lo criollo en cuestión. Buenos Aires: Katatay.

Gadet, Françoise, Ralph Ludwig, Lorenza Mondada, Stefan Pfänder and AnneCatherine Simon. 2012. Un grand corpus de français parlé: le CIEL-F. Choix épistémologiques et réalisations empiriques. Revue Française de Linguistique Appliquée, 17 (1): 39-54.

Harris, Alice C., and Lyle Campbell. 1995. Historical Syntax in a Crosslinguistic Perspective. Cambridge: Cambridge University Press.

Haspelmath, Martin. 1998. Does Grammaticalization need Reanalysis? Studies in Language 22 (2): 49-85.

Heine, Bernd, and Tania Kuteva. 2002. World Lexicon of Grammaticalization. Cambridge: Cambridge University Press.

Hilpert, Martin, and Diessel Holger. 2016. Entrenchment in Construction Grammar. In Entrenchment, Memory and Automaticity. The Psychology of Linguistic Knowledge and Language Learning, ed. Hans-Jörg Schmid, 45-59. Berlin and Boston: American Psychology Association and Mouton de Gruyter.

Holder, Gérard. 1988. Tipolo en colonie de vacances. Cayenne: Imprimerie Municipale.

Honorien, Louis. 2010. Le kréyòl. In Langues de Guyane, ed. Odile RenaultLescure and Laurence Goury, 119-132. IRD: Marseille.

Hopper, Paul J., and Elisabeth C. Traugott. 2003. Grammaticalization, 2nd ed. Cambridge: Cambridge University Press.

Horth, Auguste. 1948. Le patois guyanais. Cayenne: Paul Laporte. 
Jarvis, Scott, and Aneta Pavlenko. 2008. Crosslinguistic Influence in Language and Cognition. New York and London: Routledge.

Jean-Louis, Marie-Paule. 1987. La tradition Orale Guyanaise. Universalité et spécificité du conte créole. Unpublished thesis, Université d'Aix-en-Provence.

Jennings, William. 1999. The Role of Cayenne in the Pernambuco-Surinam Hypothesis. In Spreading the Word: Papers on the Issue of Diffusion of Atlantic Creoles, ed. Magnus Huber and Mikael Parkvall, 141-150. London: University of Westminster Press.

Jennings, William, and Stefan Pfänder. 2015. French Guianese Creole. Journal of Language Contact 8 (1): 36-69.

Kerswill, Paul. 1996. Children, Adolescents, and Language Change. Language Variation and Change 8 (2): 177-202. Cambridge: Cambridge University Press.

Kerswill, Paul. 2006. Koineization and Accommodation. In The Handbook of Language Variation and Change, ed. Jack K. Chambers, Peter Trudgill, and Natalie Schilling-Estes. Malden, MA and Oxford: Blackwell.

Kriegel, Sibylle (ed.). 2003. Grammaticalisation et réanalyse. Approches de la variation créole et française. Paris: CNRS Éditions.

Kriegel, Sibylle, Ludwig Ralph, and Henri Fabiola. 2009. Les rapports entre créole et bhojpouri à Maurice: contact de langues et actes identitaires. In Multiple Identities in action: Mauritius and Some Antillean parallelisms, ed. Vinesh Hookoomsing, Ralph Ludwig, and Burkhard Schnepel, 203-252. Frankfurt a. M.: Peter Lang, Sprache-Identität-Kultur.

Kriegel, Sibylle, Ludwig Ralph, and Salzmann Tabea. 2017 (in press). Reflections on Discourse Ecology and Language Contact: The Crucial Role of Some Scalar Terms. In Linguistic Ecology and Language Contact, ed. Ralph Ludwig, Ludwig Mühlhäusler, and Steve Pagel. Cambridge: Cambridge University Press.

Krug, Manfred. 2003. Frequency as a Determinant in Grammatical Variation and Change. In Determinants of Grammatical Variation in English, ed. Günter Rohdenburg and Britta Mondorf, 7-67. Berlin and Boston: De Gruyter.

Labov, William. 1963. The Social Motivation of a Sound Change. WORD 19 (3): 273-309.

Lafage, Suzanne. 1985. Français écrit et parlé en pays éwé: sud-Togo. Paris: SELAF. 
Lang, Jürgen, and Ingrid Neumann-Holzschuh. 1999. Reanalyse and Grammatikalisierung in den Romanischen Sprachen. Tübingen: Niemeyer.

Langacker, Ronald W. 1987. Foundations of Cognitive Grammar. Vol. 1: Theoretical Prerequisites. Stanford: Stanford University Press.

Léglise, Isabelle, and Bettina Migge (eds.). 2007. Pratiques et représentations linguistiques en Guyane: Regards croisés. Paris: IRD Éditions.

Lohier, Michel. 1960. Légendes et contes folkloriques guyanais. Cayenne: Laporte.

Lorenz, David. 2012. The Perception of 'Gonna' and 'Gotta': A study of Emancipation in Progress. In Proceedings of the 5th ISEL Conference on Experimental Linguistics, ed. Antonis Botinis, 77-80. Athens: University of Athens and International Speech Communication Association.

Lorenz, David. 2013. Contractions of English Semi-Modals: The Emancipating Effect of Frequency. In New Ideas in Human Interaction (NIHIN). Freiburg: Universitätsbibliothek.

Ludwig, Ralph. 1996. Kreolsprachen zwischen Mündlichkeit und Schriftlichkeit: zur Syntax und Pragmatik atlantischer Kreolsprachen auf französischer Basis. Tübingen: ScriptOralia and Narr.

Ludwig, Ralph, and Stefan Pfänder. 2003. La particule 'là en français oral et en créole caribéen: grammaticalisation et contact de langues. In Grammaticalisation et réanalyse: approche de la variation créole et française, ed. Sibylle Kriegel, 269-284. Paris: Éditions du CNRS.

Martel, Pierre, and Norman Beauchemin. 1973. Échantillon de textes libres. Recherches sociolinguistiques dans la région de Sherbrooke. Document de travail, ${ }^{\circ} 8$, Université de Sherbrooke.

Matthews, Peter H. 2014. The Concise Oxford Dictionary of Linguistics. Oxford: Oxford University Press.

Maurer, Philippe. 1998. El papiamentu de Curazao. In América Negra: panorámica actual de los estudios lingüisticos sobre variedades hispanas, portuguesas y criollas, ed. Matthias Perl and Armin Schwegler, 139-217. Frankfurt a. M.: Vervuert.

Michaelis, Susanne, Philippe Maurer, Martin Haspelmath, and Magnus Huber (eds.). 2013. The Atlas of Pidgin and Creole Language Structures. Oxford: Oxford University Press.

Migge, Bettina. 2000. The Origin of the Syntax and Semantics of Property Items in the Surinamese Plantation Creole. In Language Change and Language Contact in Pidgins and Creoles, ed. John McWorther, 201-234. Amsterdam: John Benjamins. 
Milroy, James, and Lesley Milroy. 1985. Linguistic Change, Social Network and Speaker Innovation. Journal of Linguistics 21 (2): 339-384.

Mondada, Lorenza, and Stefan Pfänder. 2016. Corpus international écologique de la langue française (CIEL-F): un corpus pour la recherche comparée sur le français parlé. Corpus n ${ }^{\circ}$ 15: 135-163.

Neumann-Holzschuh, Ingrid, and Edgar W. Schneider (eds.). 2000. Degrees of Restructuring in Creole Languages. Amsterdam: John Benjamins.

Neumann-Holzschuh, Ingrid. 2003. Formes invariables en créole - un cas de réanalyse. In Grammaticalisation et réanalyse: approches de la variation créole et français, ed. Sibylle Kriegel, 69-86. Paris: CNRS.

Palacios, Azucena, and Stefan Pfänder. 2014. Similarity Effects in Language Contact. In Congruence in Contact-Induced Language Change: Language Families, Typological Resemblance, and Perceived Similarity, ed. Juliane Besters-Dilger et al., 219-238. Berlin: De Gruyter.

Parépou, Alfred. 1885. Atipa: Roman Guyanais. Translated and Annotated by Marguerite Fauquenoy (1987). Paris: l'Harmattan.

Pasch, Helma. 1995. Kurzgrammatik des Ewe. Köln: Rüdiger Köppe.

Patrick, Peter L. 2006. The Speech Community. In The Handbook of Language Variation and Change, ed. Jack K. Chambers, Peter Trudgill, and Natalie Schilling-Estes, 573-597. Malden, MA/Oxford: Blackwell.

Peyraud, Flore. 1983. Structures de l'énoncé en créole guyanais. Doctoral thesis, Université de Paris III.

Pfänder, Stefan. 1996. Il n'y a pas d'Histoire...: L'expression du temps passé en créole guyanais. Études Créoles 19 (2): 31-46.

Pfänder, Stefan. 2000a. Aspekt und Tempus im Frankokreol. Semantik und Pragmatik 'grammatischer Zeiten' im Kreol unter besonderer Berücksichtigung von Französisch-Guyana und Martinique. Tübingen: Narr.

Pfänder, Stefan. 2000b. Le créole guyanais: Témoin d'une phase plus ancienne de la créolisation? Etudes Créoles 23 (2): 101-116.

Pfänder, Stefan. 2003. Réanalyse et métonymie: vers un modèle évolutif de la modalité. In Grammaticalisation et réanalyse. Approches de la variation créole et française, ed. Sibylle Kriegel, 203-215. Paris: CNRS Éditions.

Pfänder, Stefan in collaboration with Juan Ennis, Mario Soto and España Villegas. 2009. Gramática mestiza: Presencia del quechua en el castellano boliviano. La Paz: Academia de la Lengua.

Pfänder, Stefan. 2013. Guyanais. In Atlas of Pidgin and Creole Languages (APICS), ed. Martin Haspelmath, Magnus Huber, Philippe Maurer, and Susanne Michaelis. Oxford: Oxford University Press. 
Pfänder, Stefan, and Heike Behrens. 2016. Experience Counts: An Introduction to Frequency Effects in Language. In Experience Counts: Frequency Effects in Language Acquisition, Language Change, and Language Processing, ed. Heike Behrens and Stefan Pfänder, 2-20. Berlin: De Gruyter. Ploog, Katja. 2000. La syntaxe du premier actant: entre contraintes morphosyntaxiques et élaboration discursive. Étude d'un corpus parlé abidjanais, thèse de doctorat d'université, Toulouse.

Poplack, Shana, and Sali Tagliamonte. 1996. Nothing in Context: Variation, Grammaticization and Past Time Marking in Nigerian Pidgin English. In Changing Meanings, Changing Functions. Papers Relating to Grammaticalization in Contact Languages, ed. Philip Baker and Anand Syea, 71-94. London: University of Westminster Press.

Rosemeyer, Malte. 2014. Auxiliary Selection in Spanish. Gradience, Gradualness, and Conservation. Amsterdam and Philadelphia: John Benjamins.

Saint-Jacques Fauquenoy, Marguerite. 1972. Analyse structural du créole guyanais. Paris: Klincksieck.

Saint-Jacques Fauquenoy, Marguerite. 1974. Guyanese: A French creole. In Pidgins and Creoles: Current Trends and Prospects, ed. David DeCamp and Ian F. Hancock, 27-37. Georgetown: Georgetown University Press.

Saint-Quentin, Auguste de. 1872. Etude sur la grammaire créole. In Introduction à l'histoire de Cayenne, ed. Alfred de Saint-Quentin. Antibes: Marchand.

Schlupp, Daniel. 1997. Modalités prédicatives, modalités aspectuelles et auxiliaires en créole à base lexicale française de la Guyane française (XVIIIe-XXe siècles). Tübingen: M. Niemeyer.

Seton, Bregtje, and Monika S. Schmid. 2016. Multi-Competence and First Language Attrition. In The Cambridge Handbook of Linguistic Multi-Competence, ed. Vivian Cook and Li Wei, 338-354. Cambridge: Cambridge University Press.

Siegel, Jeff. 2007. Transmission and transfer. In Deconstructing Creole, ed. Umberto Ansaldo, Stephen Matthews, and Lisa Lim. Amsterdam: John Benjamins.

Siegel, Jeff. 2008a. The Emergence of Pidgin and Creole Languages. Oxford: Oxford University Press.

Siegel, Jeff. 2008b. In Praise of the cafeteria Principle. Language Mixing in Hawai'i Creole. In Roots of Creole Structures. Weighing the Contribution of Substrates and Superstrates, ed. Susanne Michaelis, 59-82. Amsterdam: John Benjamins. 
Siegel, Jeff. 2010. Bilingual Literacy in Creole Contexts. Journal of Multilingual and Multicultural Development 31 (4): 383-402.

Siegel, Jeff. 2012. Two Kinds of Functional Transfer in Language Contact. Journal of Language Contact 5 (2): 187-215.

Siegel, Jeff. 2015. The Role of Substrate Transfer in the Development of Grammatical Morphology in Language Contact Varieties. Word Structure 8 (2): 160-183.

Sournia, Jean-Charles. 1976. Une rareté: un texte administratif en créole. Banque des mots 11: 3-8.

Stäbler, Cynthia. 1995. La vie dans le temps et asteur. Ein Korpus von Gesprächen mit Cadiens in Lousiana. Tübingen: Narr.

Stolz, Thomas. 1987. The Development of the Aux-Category in Pidgins and Creoles: The Case of the Resultative-Perfective and its Relation to Anteriority. In Historical Development of Auxiliaries, ed. Martin Harris and Paolo Ramat, 291-316. Berlin: Mouton de Gruyter.

Szmrecsanyi, Benedikt. 2006. Morphosyntactic Persistence in Spoken English: A Corpus Study at the Intersection of Variationist Sociolinguistics, Psycholinguistics, and Discourse Analysis. Berlin and New York: de Gruyter.

Tchang, Laurent. 1988. Les contes créoles de Guyane, témoins de la créolisation culturelle. Aix-en-Provence (corpus ms.).

Warburton, Irene, Prosper Kpotufe, and Roland Glover. 1968. Ewe Basic Course. Bloomington: Indiana University.

Whitney, William D. 1979 [1875]. The Life and Growth of Language: An Outline of Linguistic Science. New York: Dover.

Wiesinger, Evelyn. 2015. Le syntagme nominal en créole guyanais: Une étude synchronique et diachronique du marqueur LA. Doctoral thesis, Universities of Regensburg and Aix-Marseille.

Wiesmath, Raphaële. 2000. Enchaînement des propositions dans le français acadien du Nouveau-Brunswick, Canada. Doctoral thesis, University of Freiburg.

Wiesmath, Raphaële. 2003. La particule là dans le parler acadien du NouveauBrunswick, Canada. In Grammaticalisation et réanalyse. Approches de la variation créole et française, ed. Sibylle Kriegel, 284-302. Paris: Éditions CNRS.

Winford, Donald. 2003. An Introduction to Contact Linguistics. Oxford: Blackwell.

Winford, Donald, and Bettina Migge. 2007. Substrate Influence in the Emergence of the Tense and Aspect System in the Creoles of Suriname. Journal of Pidgin and Creole Languages 22 (1): 73-99. 
Open Access This chapter is licensed under the terms of the Creative Commons Attribution 4.0 International License (http://creativecommons. org/licenses/by/4.0/), which permits use, sharing, adaptation, distribution and reproduction in any medium or format, as long as you give appropriate credit to the original author(s) and the source, provide a link to the Creative Commons license and indicate if changes were made.

The images or other third party material in this chapter are included in the chapter's Creative Commons license, unless indicated otherwise in a credit line to the material. If material is not included in the chapter's Creative Commons license and your intended use is not permitted by statutory regulation or exceeds the permitted use, you will need to obtain permission directly from the copyright holder. 